\title{
أساليب التعلم في ضوء نظرية روميرو وتيبير وعلاقتها ببعض المتغيرات
}

\section{لاى طالبات الاراسة الإعدادية}

أ.م.د عبود جواد راضي

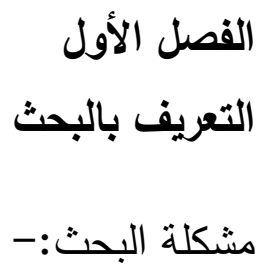

أحس الباحث بمشكلة البحث الحالي من خلال خبرته العملية والعلمية وتخصصه في مجال علم النفس التربوي إذ شعر أنّ ضعف اهنمام أغلب أعضاء الهيئات التدريسية بتحديد أساليب تعلم الطلبة يؤدي إلى انخفاض مستوى التحصيل الدراسي لهؤلاء الطلبة وارتفاع نسبة الرسوب لديهم مما يولد الثعور

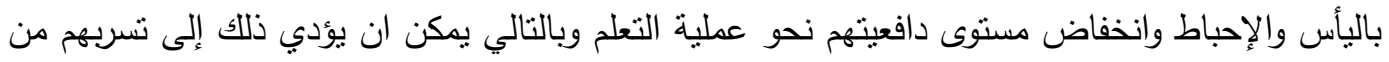

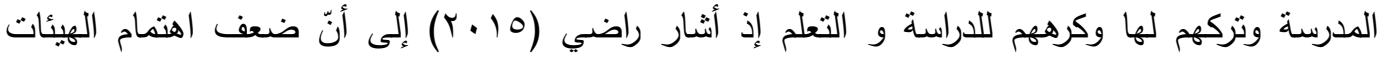

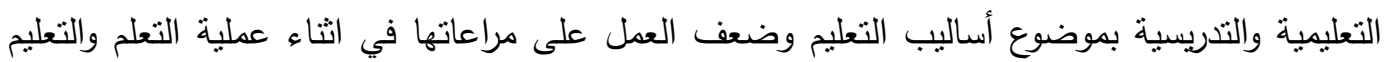

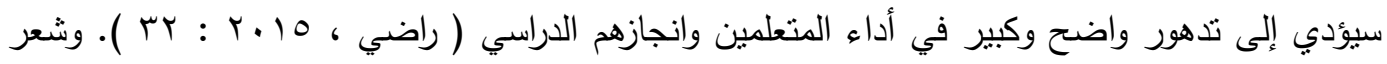
الباحث بوجود هذه المشكلة من خلال القراءات الناقدة والنظريات الفاحصة لكثير من الدراسات المسحية

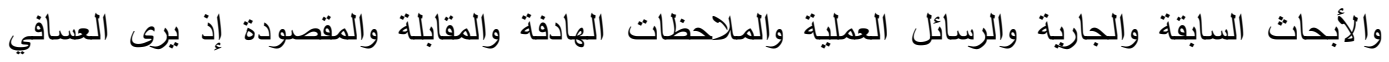
(919 1 ) أنّ من أبرز الطرائق التي تساعد الباحث على الاختيار السليم والدقيق لمشكلة البحث هي الخبرة

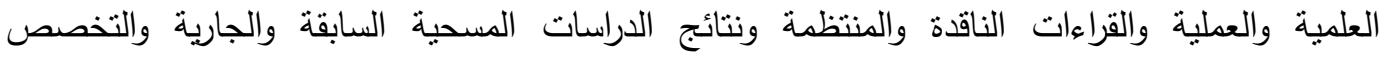

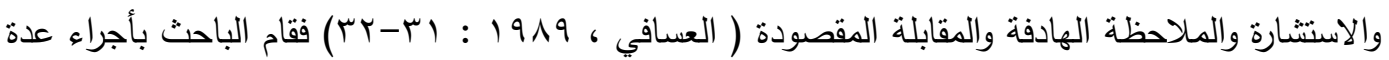

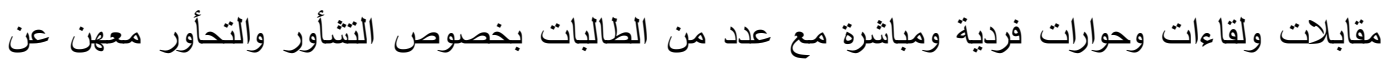

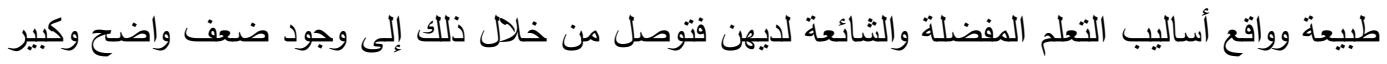
في انباع تلك الطالبات لأساليب التعلم الصحيحة والفعالة المختلفة وتوصل إلى أنّ انخفاض مستوى ألى أداء

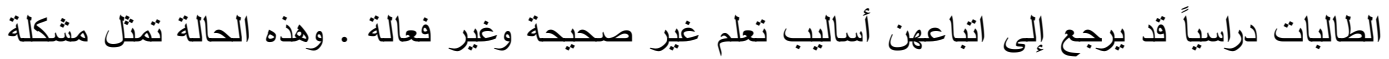


كبرى نواجه عملية التعلم والتعليم في معظم مدارسنا الإعدادية بصورة عامة وكذلك استعمل الباحث أداة

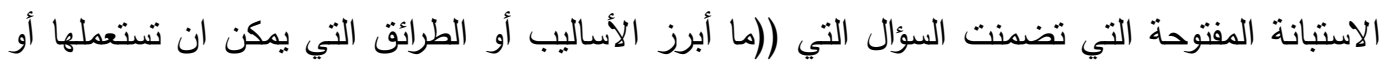

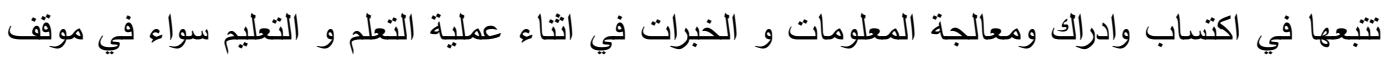

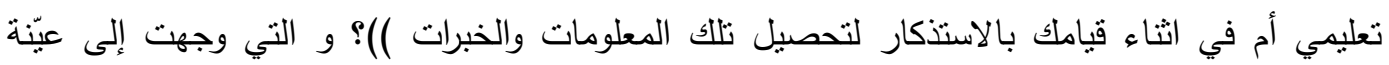

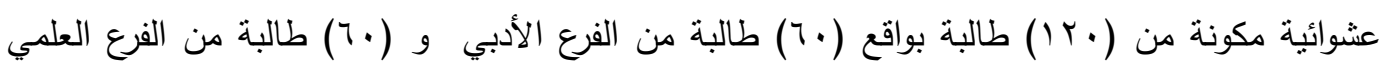

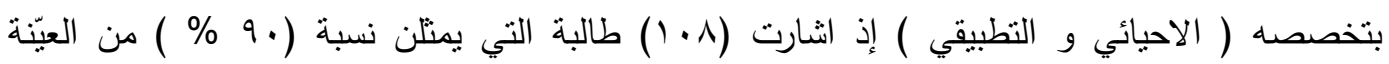

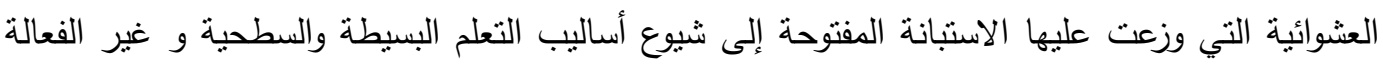

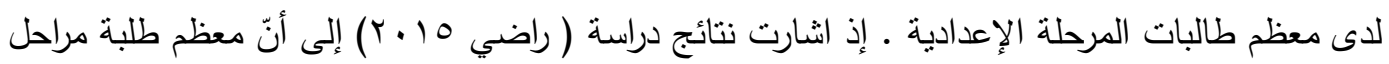
الدراسة المتوسطة والإعدادية يميلون إلى اتباع أساليب غير فعالة وسطحية وغير مجدية في عملية التعلم

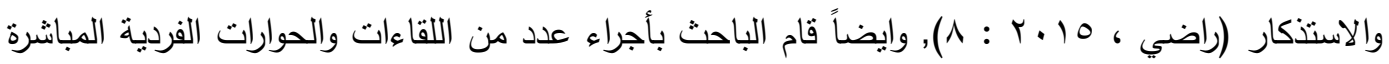

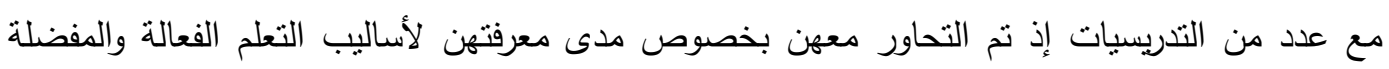
لاى طالباتهن ومدى اهتمامهن بتحديد وتتشخيص هذه الأساليب فكانت إجابات معظمهن أنيّنّ لا يعرفن

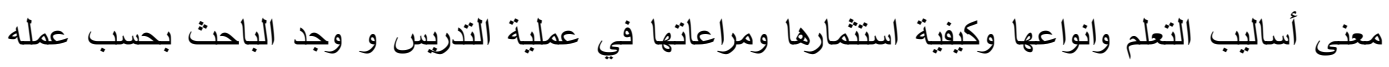

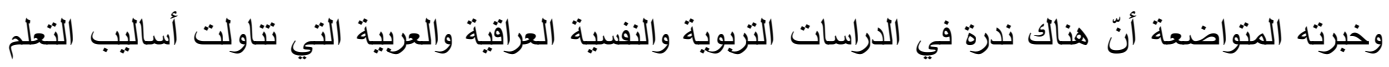

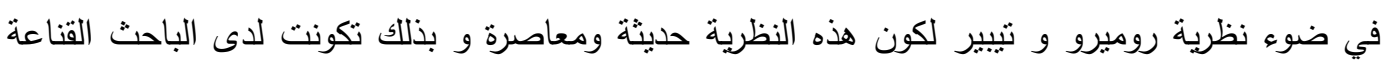

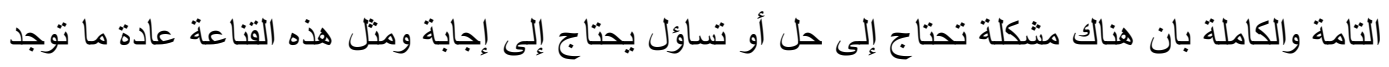

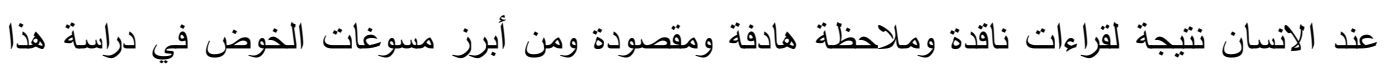

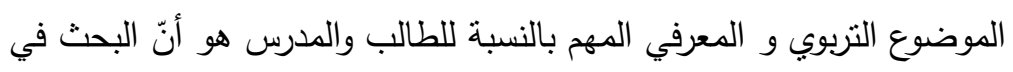

أساليب التعلم يمثل اتجاهات جديداً في مجال علم النفس التربوي إذ يؤكد هذا الاتجاه على الاهتمام بعملية

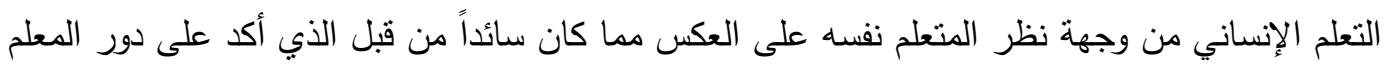

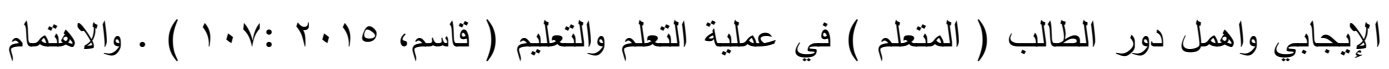

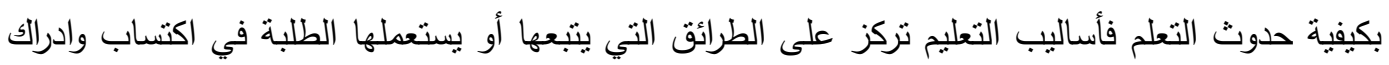

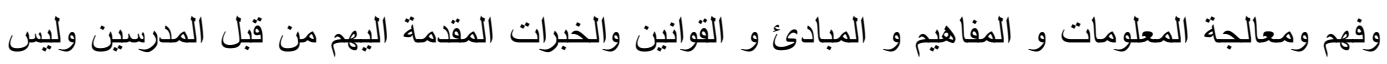

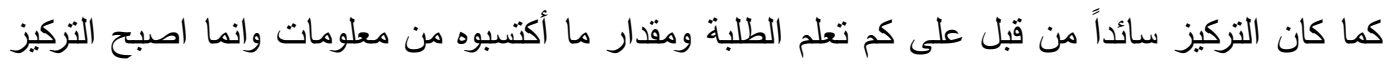

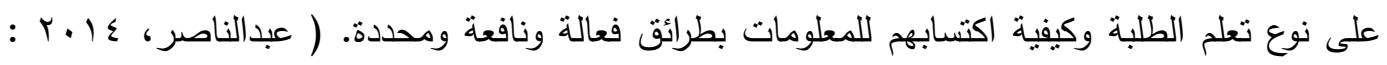

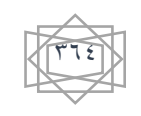


1/11 ) وانطلاقاً مما سبق أرتأى الباحث الخوض في غمار هذا الموضوع الحيوي والمهم لجميع الطلبة

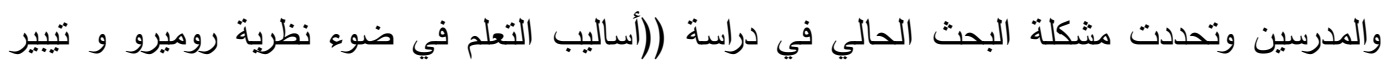

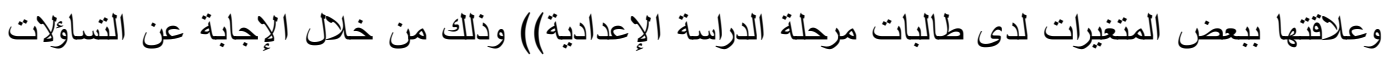

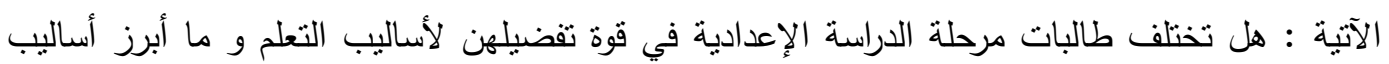

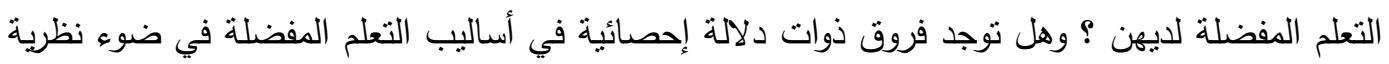

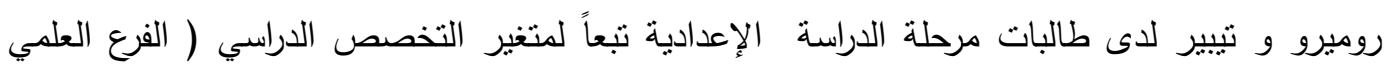

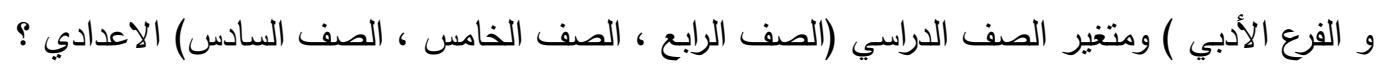

أهمية البحث : تُعدّد أساليب التعلم من الدفاهيم الحديثة التي ظهرت نتيجة البحث في علم النفس

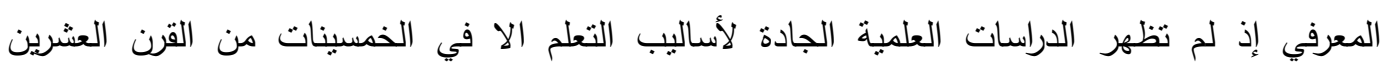

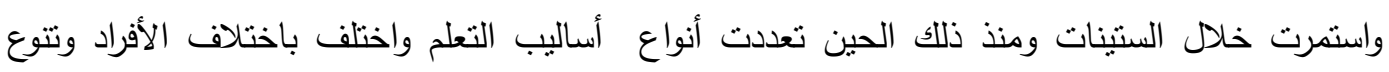

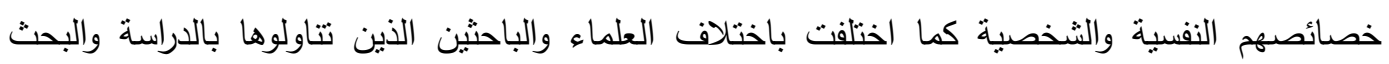

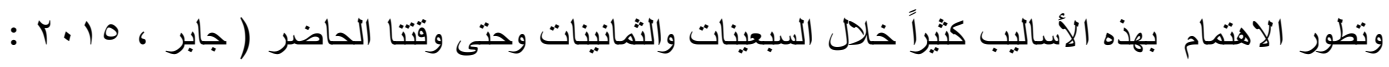

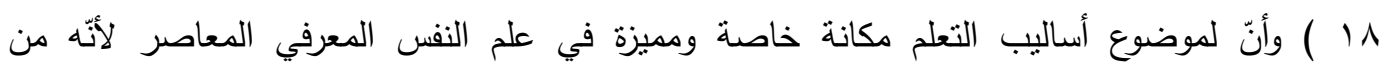

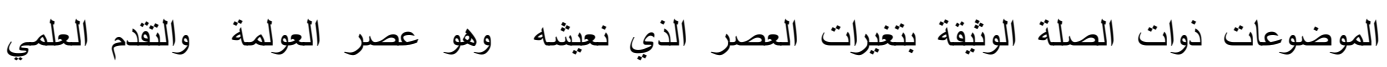

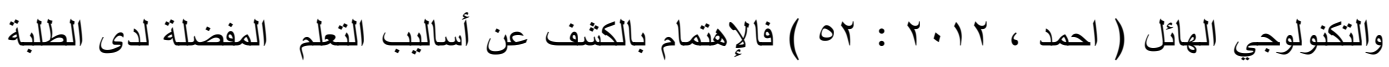

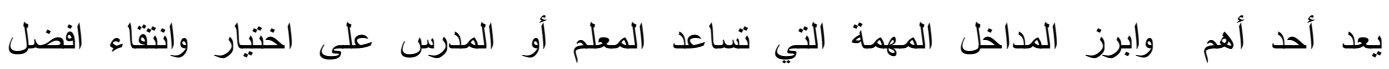
الاستراتيجيات والطرائق والأساليب التدريسية المناسبة والفعالة لتوصيل المادة العلمية بكل مهارة واتقان التهان

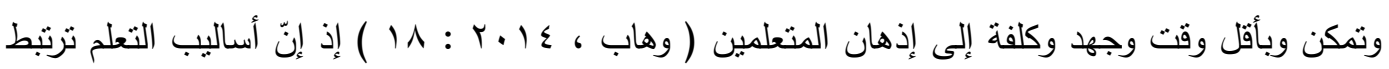

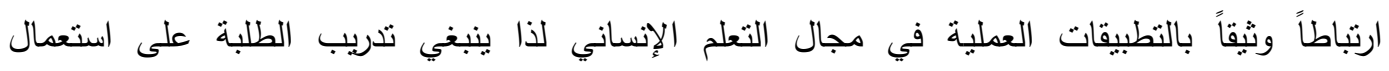

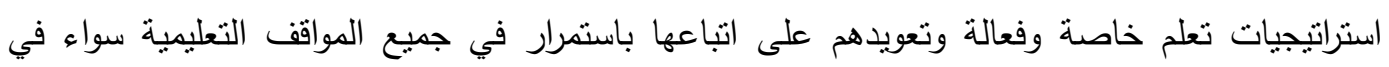

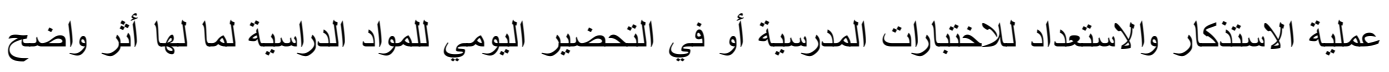

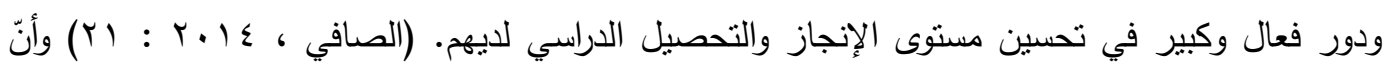

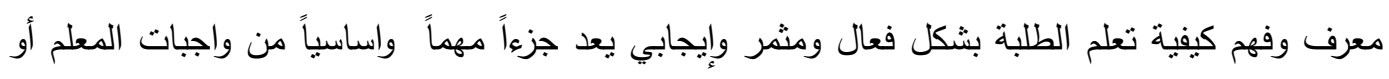

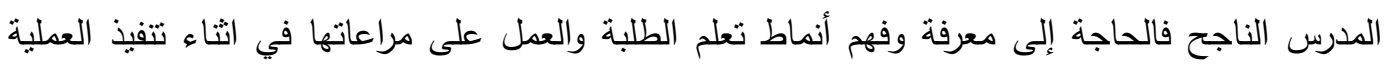

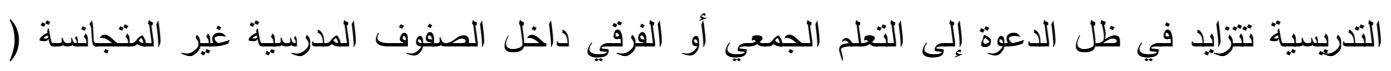




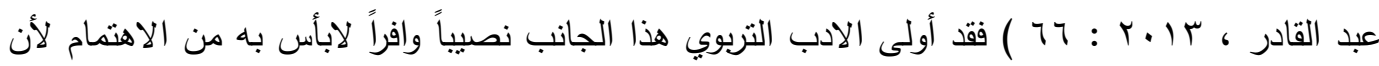

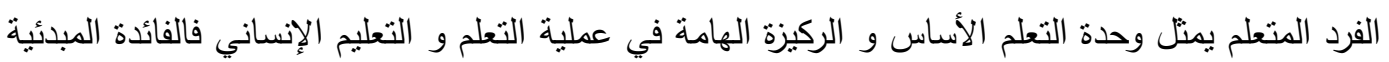

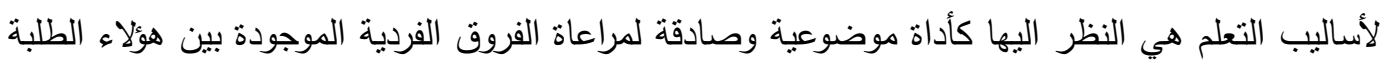

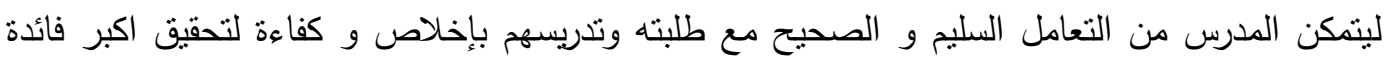

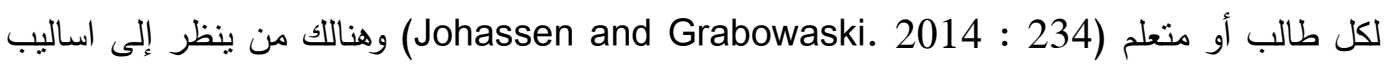
التعلم على انها طرائق و أساليب شخصية مفضلة يستعملها الفرد المتعلم في التعامل مع المعلومات في

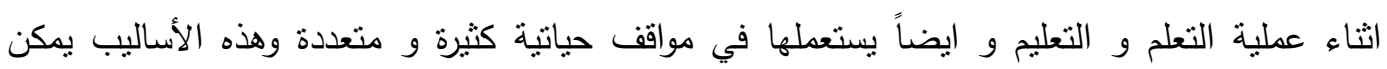

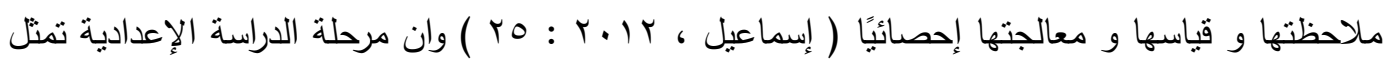

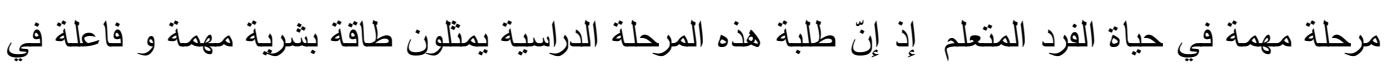

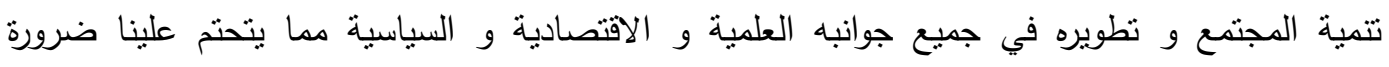

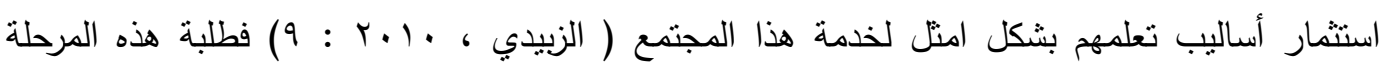

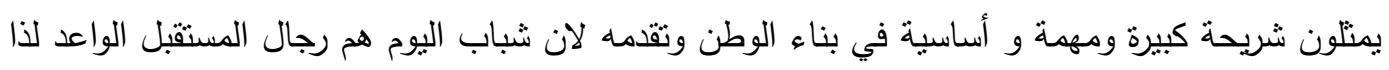

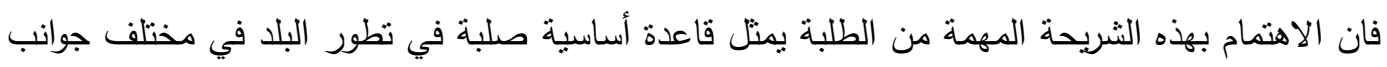

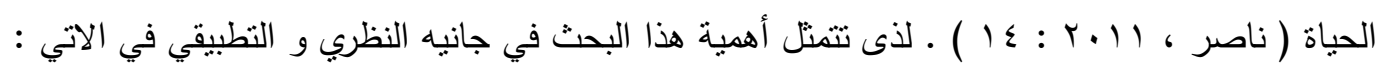

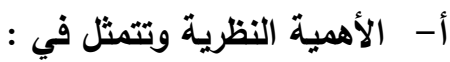

1- يعّد هذا البحث إضافة نوعية جديدة للدراسات العراقية و العربية في مجال أساليب التعلم إذ يساعد أعضاء

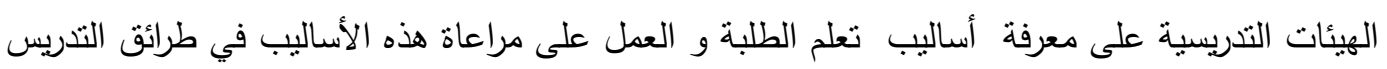

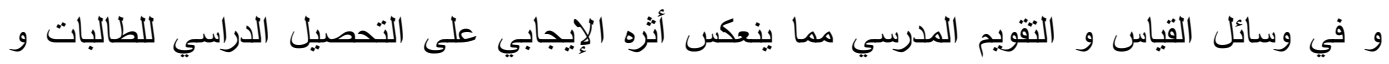

$$
\text { ارتفاع مستوى الإنجاز لديهن. }
$$

ץ- يعد هذا البحث دعوه صادقة وصريحة لطلبة الدراسات العليا و الباحثين و المهتمين بدراسة أساليب التعلم

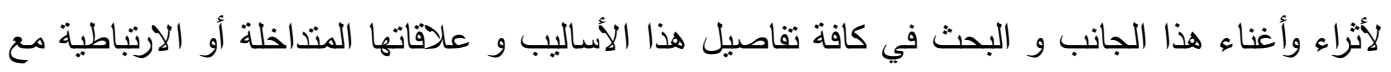

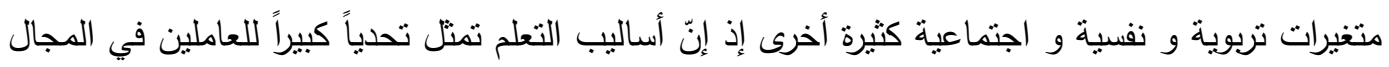

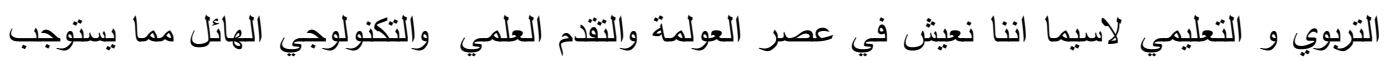

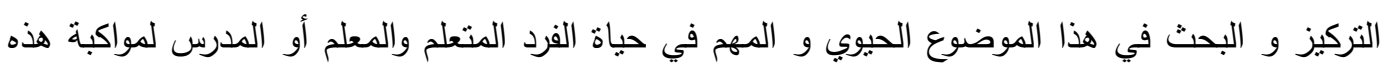
التطورات العلمية الكبيرة في جميع مجالات الحياة المختلفة. 
ب- يكتسب هذا البحث أهميته من أهمية طلبة الدراسة الإعدادية كونهم يمثلون شريحة مهمة في المجتمع فهم صناع و بناة المستقبل

ع- ترجع أهمية هذا البحث إلى تتأوله لمتغيرات جوهرية و أساسية وهي متغيرات التخصص الفرع ) الدراسي ( العلمي ، الأدبي ) ومتغير الصف ( الصف الرابع ، الصف الخامس ، الصف السادس )

\section{ب-الأهمية التطبيقية وتثمثل في :}

ا- ترجمة مقياس أساليب التعلم من اعداد روميرو و تيبير Romero and Tepper (1992) للاستفادة منه في اعداد مقياس أساليب التعلم في هذا البحث أو الاستفادة منه في اجراء دراسات لاحقة أخرى . ץ- يمكن ان تسهم نتائج هذا البحث في توجيه انظار المسؤولين و القادة القائمين على تطوير نظام التربية و التعليم في العراق بان يتم التأكيد و التركيز على موضوع أساليب التعلم المفضلة لدى طلبة الدراسة الإعدادية كي يستطيع الفرد المتعلم من ممارسة هذه الأساليب و الوسائل في تعلمه بصوره خاصة و في حياته الاجتماعية بصورة عامة. ب- ان معرفة الهيئات التدريسية لأساليب تعلم طلبتهم قد تساعدهم على اختيار وانتقاء افضل الطرائق التدريسية الحديثة ووسائل التقويم الفعالة و المناسبة التي تتلاءم مع هذه الأساليب مما يساعد على تحسين أداء المتعلمين و ارتفاع مستوى الإنجاز و التحصبل الدراسي و تحقيق الراحة و الاطمئنان النفسي لديهم. ع- تعد أساليب التعلم افضل من اختبارات القدرات التقليدية في التتبؤ بالتحصيل الدراسي إذ يرى (راضي ،

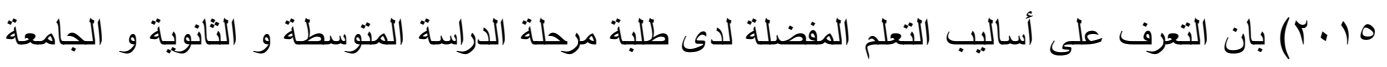
قد تساعد أعضاء الهيئات التدريسية على معرفة الطرائق التي يتعلم بها الطلبة وكيف يكتسبون المعلومات

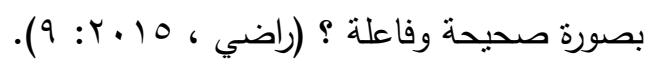


1- أساليب التعلم المفضلة في ضوء نظرية روميرو و تنيير لدى طالبات مرحلة الدراسة الإعدادية في مركز محافظة واسط / مدينة الكوت. r- دلالة الفروق الإحصائية في أساليب التعلم المفضلة في ضوء نظرية روميرو وتيبير لدى طالبات مرحلة

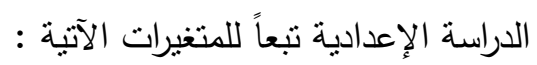

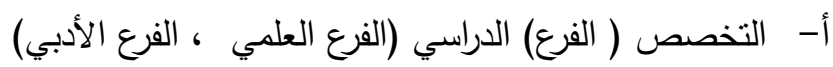
ب- متغير الصف الدراسي (الصف الرابع ، الصف الخامس ، الصف السادس) الاعدادي ولتحقيق هذه الادي

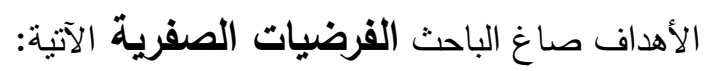
1- لا توجد فروق ذوات دلالة إحصائية عند مستوى دلالة (0. . • ) بين طالبات مرحلة الدراسة الاسة الإعدادية (عيّنة البحث) في قوة تفضيلهن لأساليب التعلم في ضوء نظرية روميرو و تنيبر ץ- أ- لا توجد فروق ذوات دلالة إحصائية عند مستوى دلالة (0. . ·) بين طالبات مرحلة الدراسة الإعدادية

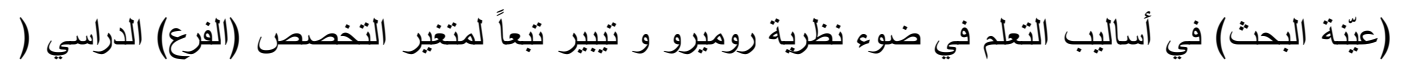

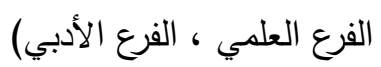
ب-لا توجد فروق فردية ذوات دلالة إحصائية عند مستوى دلالة (0.,.) بين طالبات مرحلة الدراسة

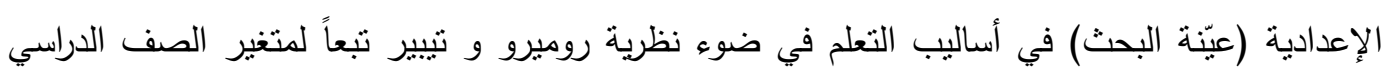
(الصف الرابع ، الصف الخامس ، الصف السادئ) الاعدادي.

حدود البحث :- يقتصر اجراء هذا البحث على عيّنة عشوائية من طالبات مرحلة الدراسة الإعدادية

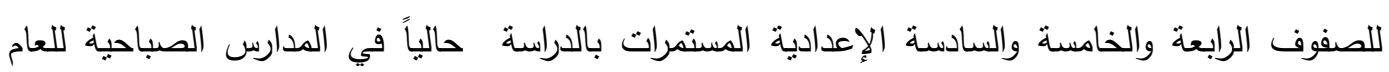

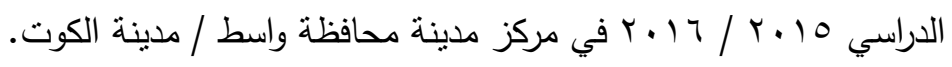


1992 أولاً: أساليب التعلم (learning styles) عرفها روميرو و تيبير (Romero and Tepper)

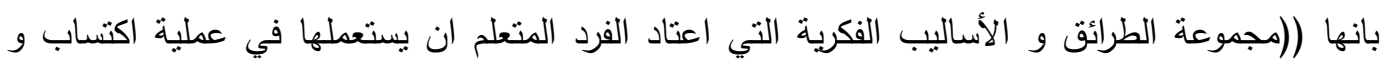
ادراك و معالجة المعلومات و الدفاهيم و الخبرات في اثثاء عملية التعلم والتعليم (Romero and Tepper. 1992 : 23) (الإنساني)

التعريف النظري:- تبنى الباحث تعريف روميرو وتيبير (1992) الدذكور في أعلاه لكونه ينسجم مع

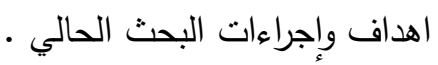

التعريف الاجرائي:- هي الدرجة التي تحصل عليها الطالبة ( المستجيبة) على فقرات مقياس أساليب التعلم في ضوء نظرية روميرو و تيبير الذي قام الباحث بترجمته إلى اللغة العربية وتكييفه للبيئة العراقية. ثانياً:- نظرية روميرو و تيبير (1992) : عرفها كلاً من روميرو وتيبير بانها ((نظرية تربوية - تعليمية-

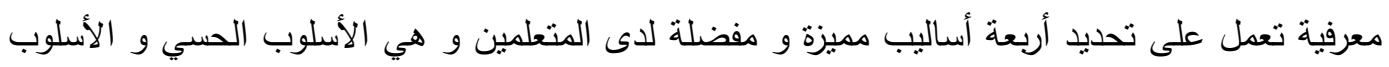

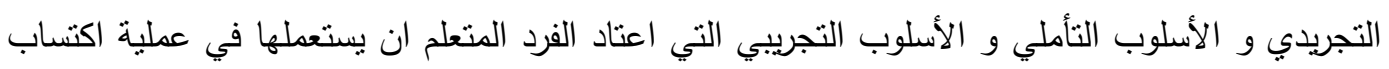

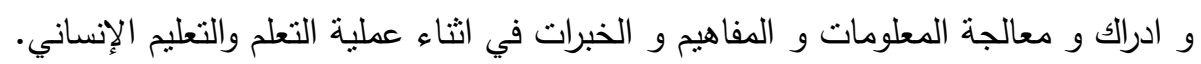


التعريف النظري:- تبنى الباحث تعريف روميرو وتيبير (1992) لكونه ينسجم مع اهداف و إجراءات

التعريف الاجرائي: - هي نظرية نربوية -تعليمية- معرفية تتضمن أربعة أساليب مميزة ومفضلة للتعلم

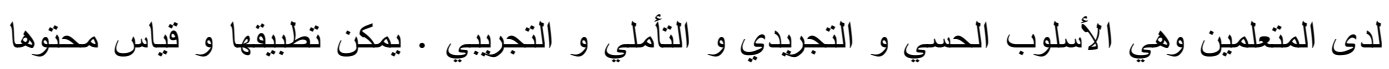

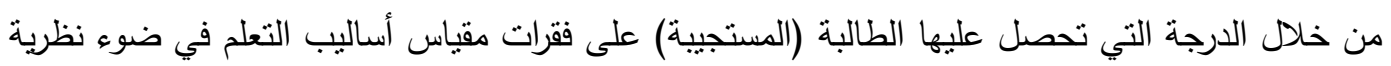
(روميرو وتيبير) الذي قام الباحث بترجمته إلى اللغة العربية وتكيفيه للبيئة العراقية.

ثالثاً:- طالبات مرحلة الدراسة الإعدادية : يعرفهن الباحث إجرائياً بأنهن أولئك الطالبات الناجحات من

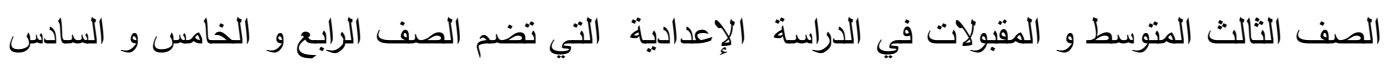

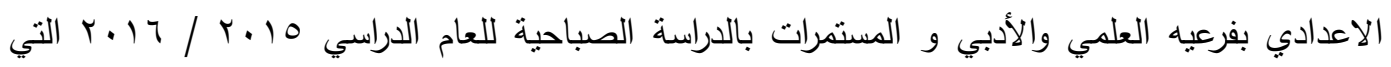
تنزأوح أعمارهن بين (17 - 11 (1) سنة. 
الفصل الثاني

$$
\text { الاطار النظري ودراسات سابقة }
$$

$$
\text { أولاً:-- الأطار النظري:- - - - }
$$

نبذة تاريخية عن نظرية روميرو وتيييز : هي أحدى النظريات النزبوية و التعليمية و المعرفية

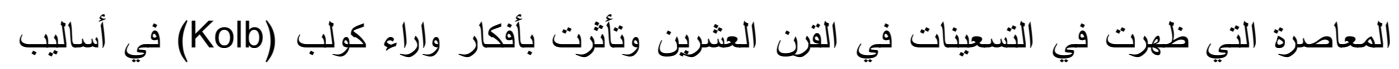

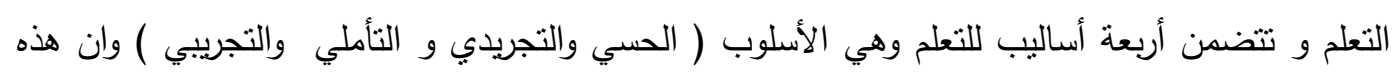

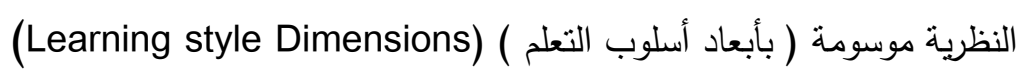

\section{مبادئ نظرية روميرو وتينيز :-}

1- الاهنمام بنوعية عمليات التعلم الإنساني بدلاً من التركيز على كمية نتائج التعلم.

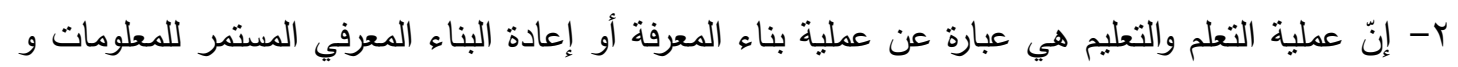

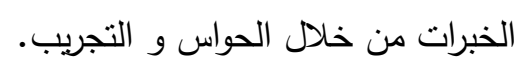

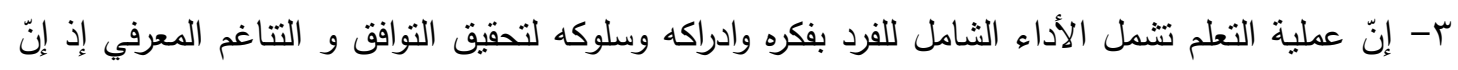

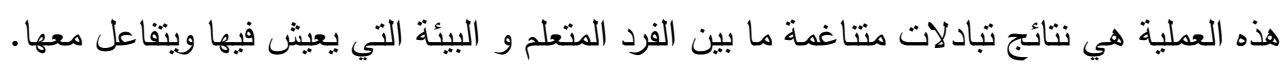
ع- إنّ عملية التعلم يمكن نسهيل وتيسير حدوثها بفعالية و نشاط لاى المتعلمين من خلال اتباعهم لأساليب

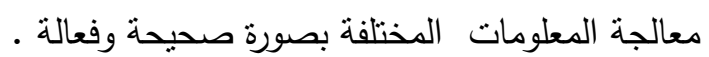

\section{أبعاد أسلوب التعلم في نظرية روميرو وتيييز:}

1- السلوب الحسي (Concrete style) إنّ طريقة اكتساب وادراك ومعالجة الفرد المتعلم للمعلومات

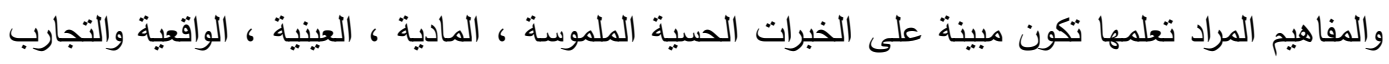

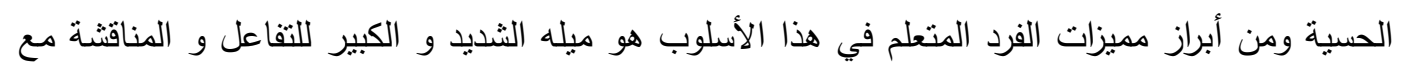

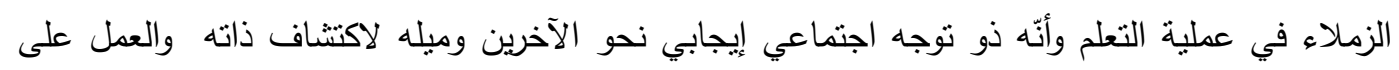




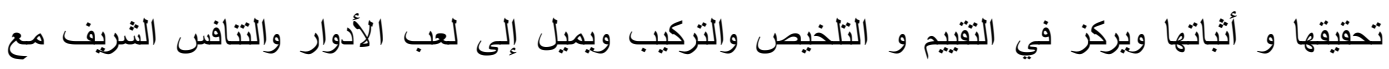

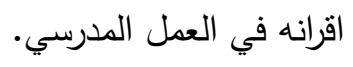
r- الأسلوب التجريدي(Conceptualization style) إنّ طريقة اكتساب وادراك ومعالجة المعلومات المراد

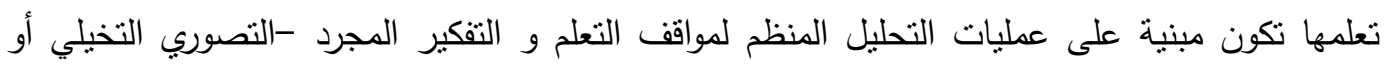

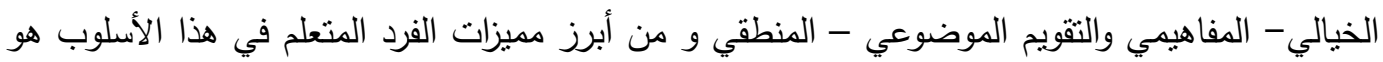

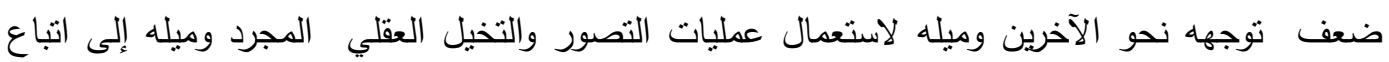
أساليب التحليل المنظم و التصنيف و المنطق العقلي في عملية التعلم الإنساني. r- الأسلوب التأملي(Reflective style) إنّ طريقة اكنساب و ادراك و معالجة المعلومات المراد تعلمها تكون مبنية على عمليات التأمل و الملاحظة الموضوعية الهادفة في تحليل مواقف التعلم ومن أبرز مميزات الفرد المتعلم في هذا الأسلوب هو ميله لأتباع أساليب الملاحظة الموضوعية الدقيقة و المقصودة وغير المتحيزة ويميل إلى العزلة والانطواء الاجتماعي ويكتسب ويعالج المعلومات بطريقة تجريدية و ينعامل مع الأفكار بطرائق تحليلية و تصنيفية. ع- الأسلوب التجريبي: (Expermantial style) إنّ طريقة اكتساب وادراك و معالجة المعلومات المراد تعلمها تكون مبنية على عمليات التجريب النشط والفعال و النطبيق العملي للأفكار و الآراء المطروحة في مواقف التعلم الانساني ومن أبرز مميزات الفرد المتعلم في هذا الأسلوب هو ميله الجاد و

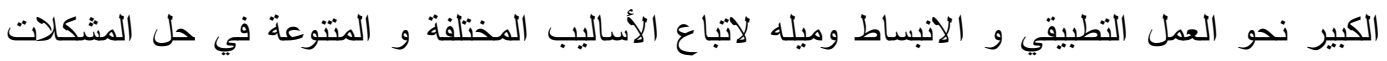

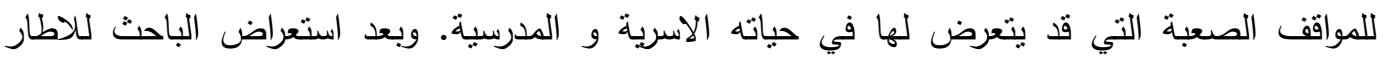
النظري اتضح له ما يأتي:-

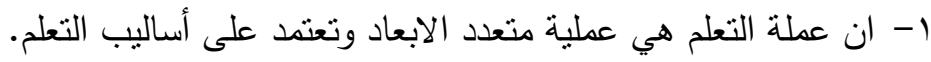

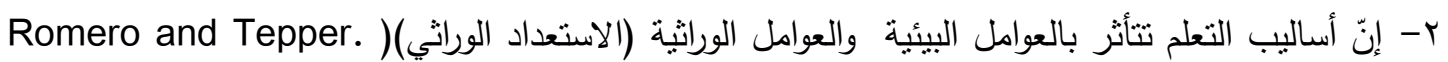
. (1992 : 37-39

\section{ثانياً:- دراسات سابقة: -}

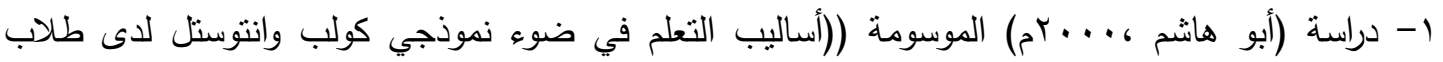

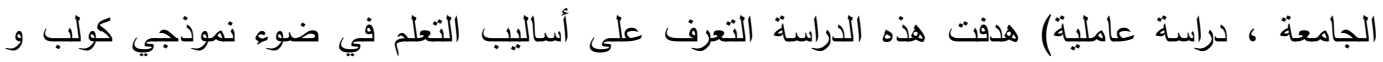

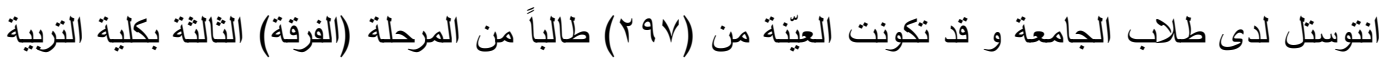
بجامعة الزقازيق و تم نطبيق استبانة أساليب التعلم من اعداد كولب kolb (1990) وترجمه أبو هانشم 


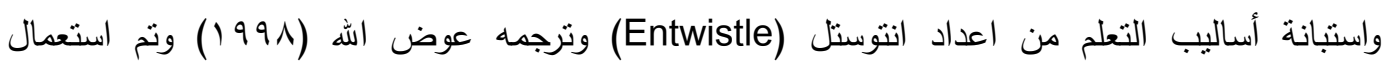

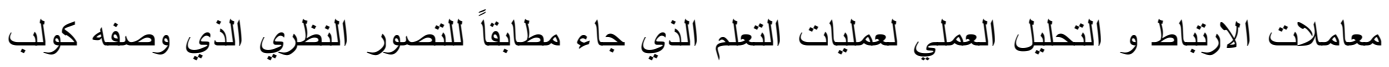

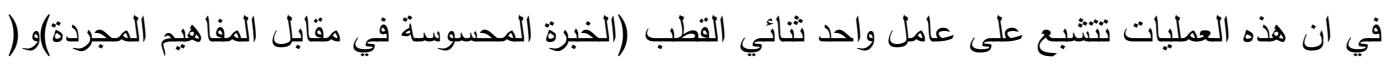

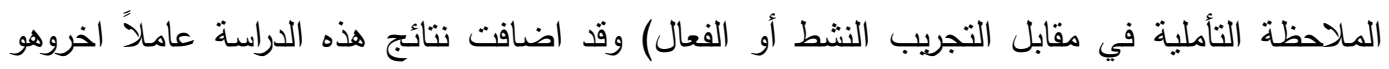

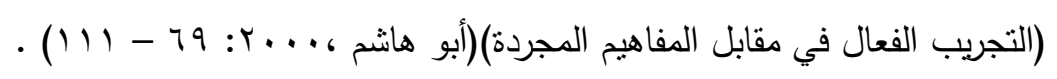

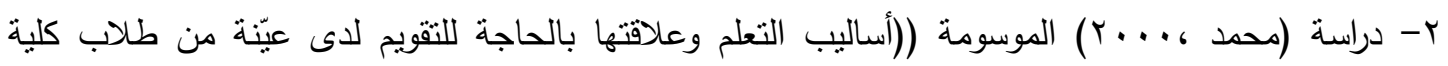

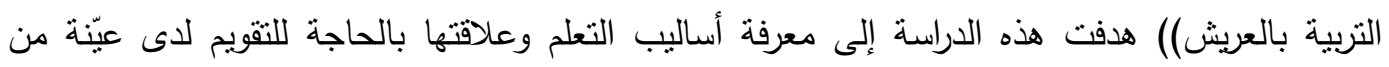

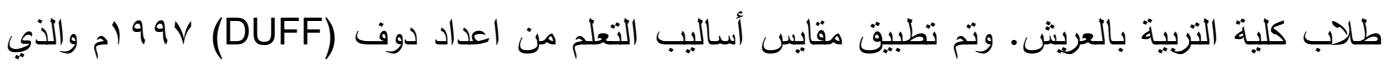

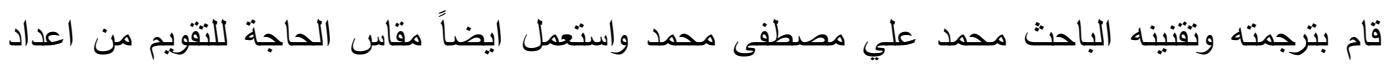

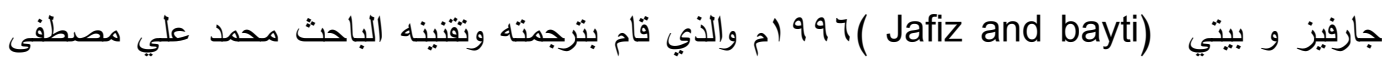

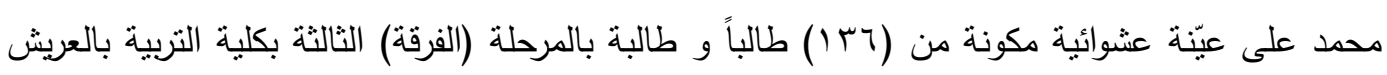

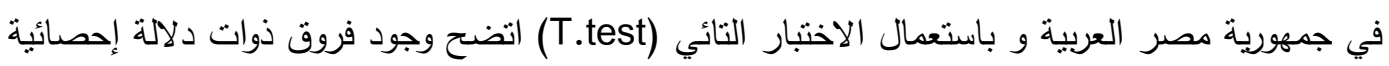

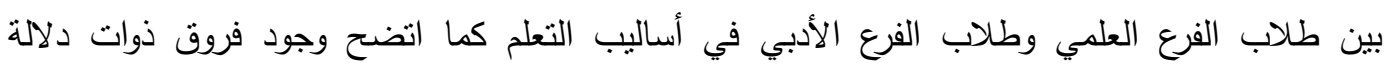

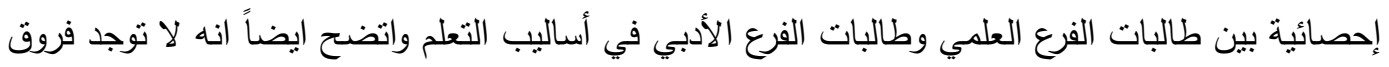

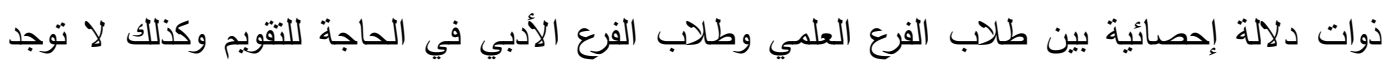

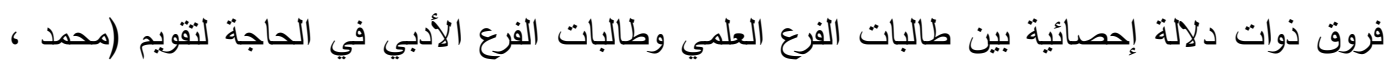
. ( $94-4$ - r...

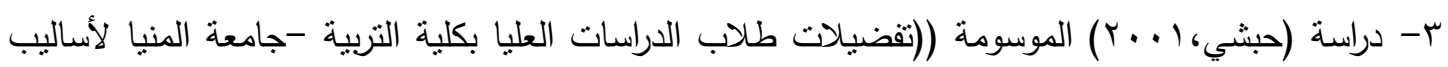

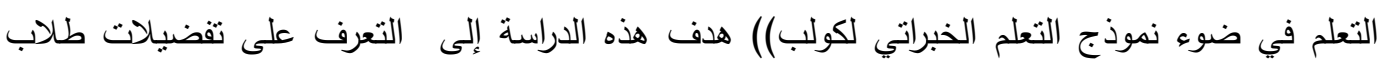

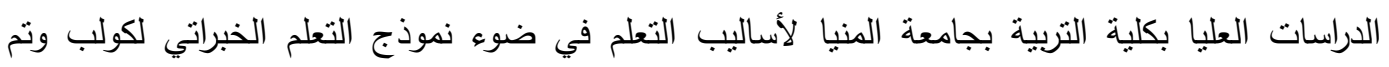

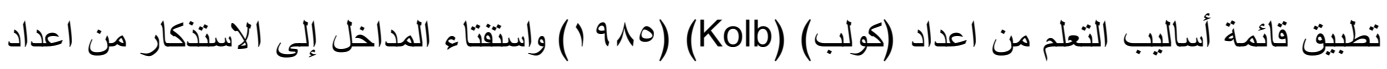

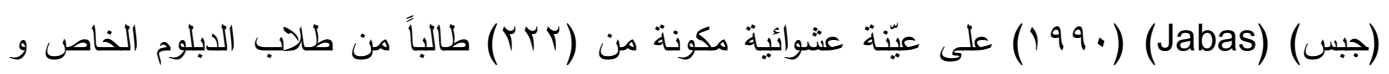

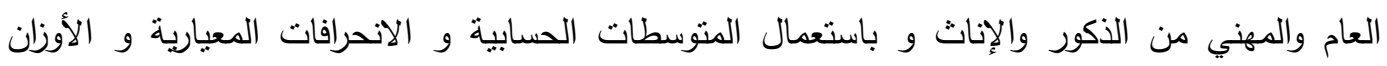

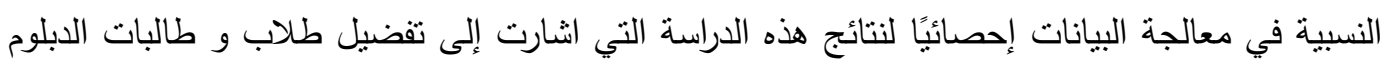

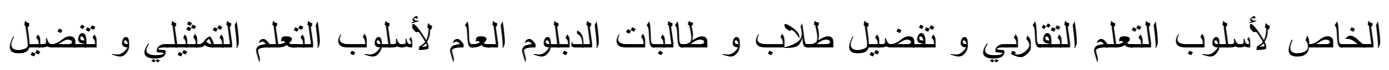

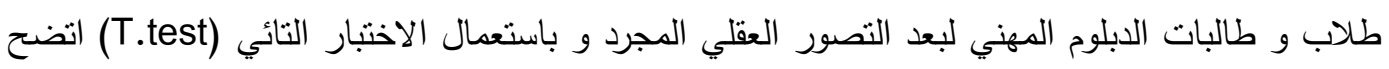

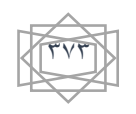


عدم وجود فروق دالة إحصائيًا بين الطلاب (الذكور) و الطالبات (الإناث) في كل من الخبرة الحسية

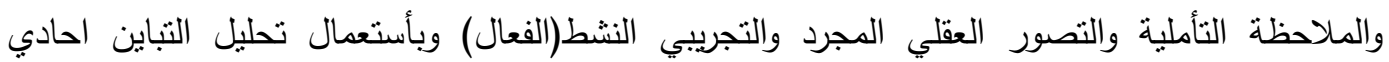
الاتجاه اتضح عدم وجود فروق دالة إحصائيًا بين طلاب الدبلوم الخاص و العام و المهني في أبعاد التعلم

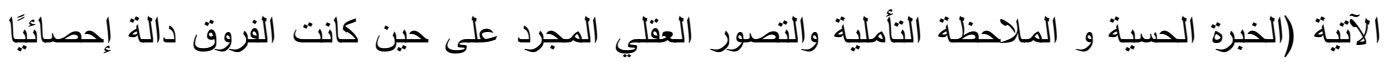

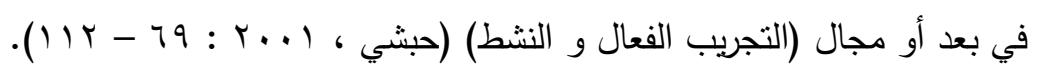

موازنة (مقارنة الدراسات السابقة مع الدراسات الحالبة:- تباينت الدراسات السابقة الثلاثة التي تناولها البحث الحالي في الجوانب الآتية:

1- الهُف: - فكان لكل من هذه الدراسات الأهداف الخاصة بها أما البحث الحالي فهدف إلى التعرف على أساليب التعلم المفضلة في ضوء نظرية روميرو وتيبير لاى طالبات مرحلة الدراسة الإعدادية في مركز محافظة واسط / مدينة الكوت.

ץ- المنهج: - تعددت المناهج المستعملة في هذه الدراسات فبعضها أستعمل المنهج الارتباطي كما في دراسة

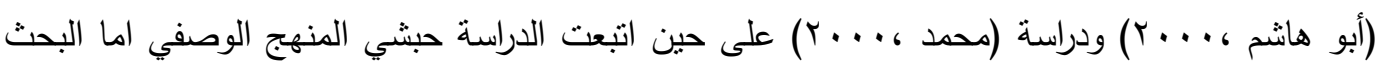

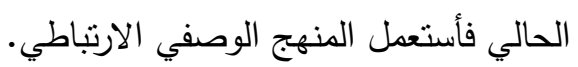
r- العيّةة: - ان معظم العينات المستعطلة في هذه الدراسات كانت من مرحلة الدراسة الجامعية ومنها دراسة الدئة

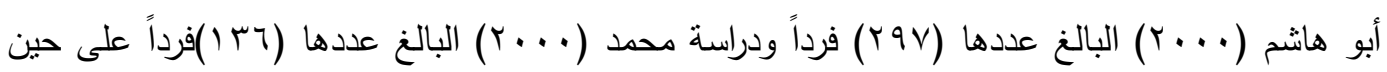

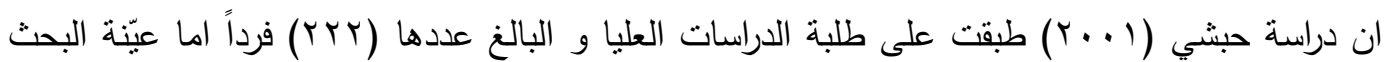
الحالي فتكونت من (^^1) طالبة من مرحلة الدراسة الإعدادية بفرعيها العلمي والأدبي.

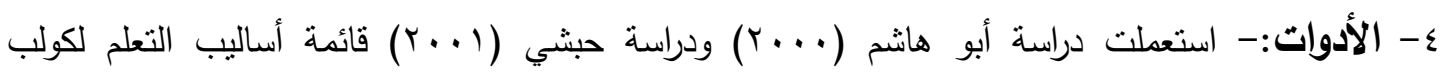

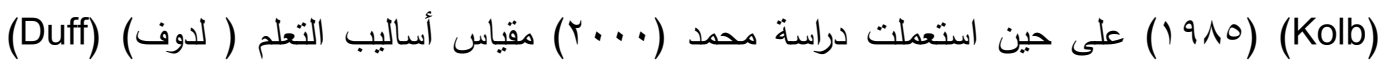

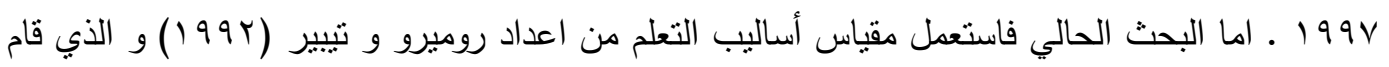
الباحث عبود جواد راضي بترجمته إلى اللغة العربية وتكييف للبيئة العراقية. 0- الوسائل الإحصائية :- اختلفت الوسائل الإحصائية المستعطلة في الدراسات السابقة التي استعرضها

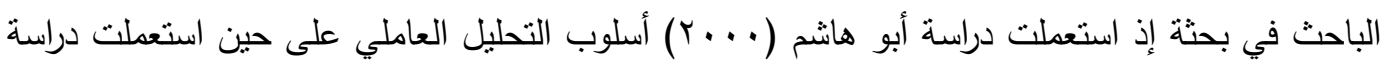




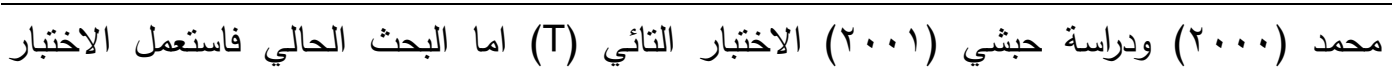

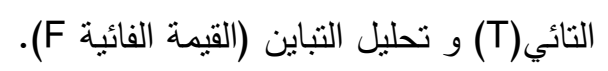

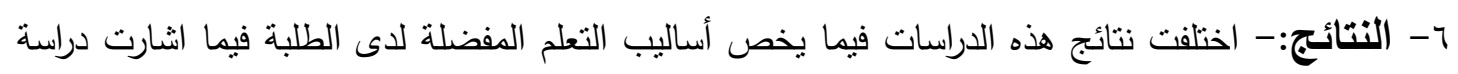

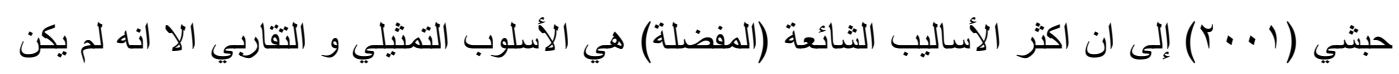

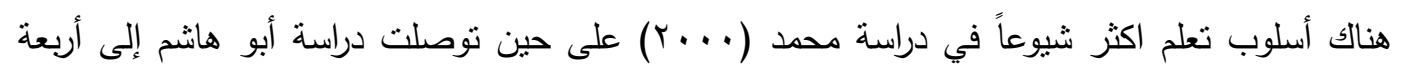

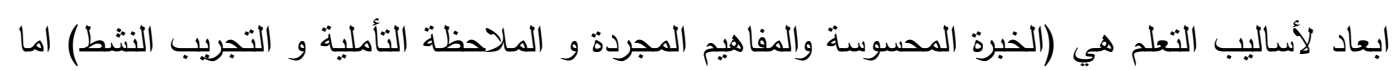
نتائج البحث الحالي فسيتم استعراضها في الفصل الرابع من هذا البحث.

جوانب الإفادة من الاراسات السابقة :- تثمثل جوانب الإفادة من الدراسات السابقة في هذا البحث بمايأتي:

1- بلورة مشكلة البحث وتحديد ابعادها ومجالاتها. r- r ت بديد مجنمع البحث وعينته.

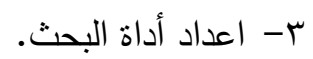

ع- التعرف على طبيعة الإجراءات البحثية التي اتبعتها هذه الدراسات. 0- اختيار الوسائل البحثية المناسبة لمعالجة وتحليل البيانات وتفسير النتائج. ؟- مقارنة نتائج الدراسات السابقة بنتائج البحث الحالي لئي 


\section{الفصل الثالث}

\section{منهج البحث واجراءاته}

أولاً:-- منهج البحث:- يمثل هذا البحث أحد البحوث الارتباطية التي تعّد من البحوث الوصفية لذا فهو يستتد إلى منهج البحث الوصفي الذي يعد الأسلوب الأمثل في دراسة مجالات الظواهر الإنسانية المختلفة إذ يهتم بتحديد أوصاف دقيقة للظاهرة المراد دراستها من حيث طبيعتها ودرجة وجودها ويتم ذلك التك

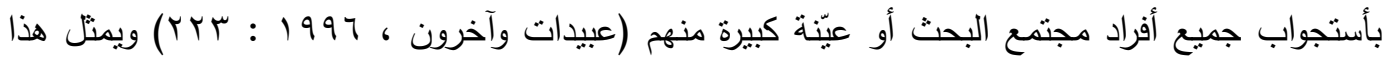

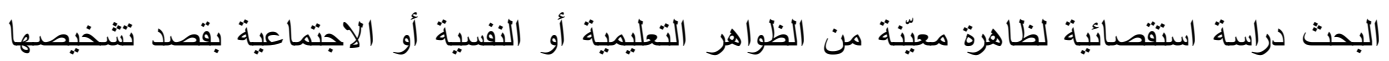

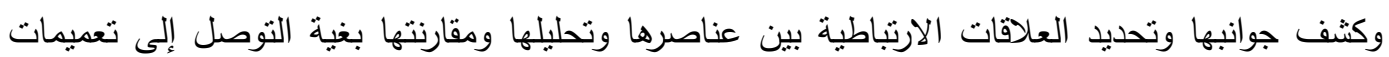

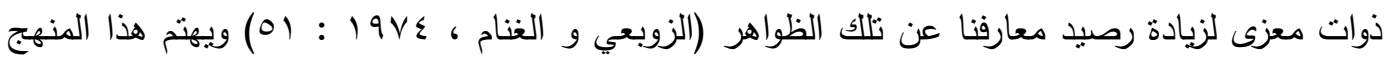

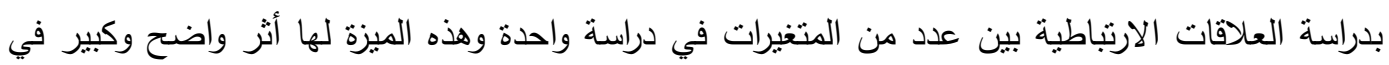

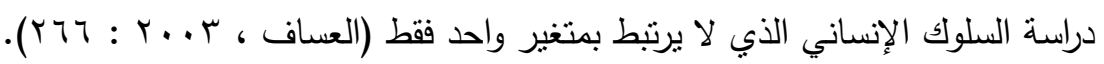

ثانياً:- مجتمع البحث تكون من (V9TY) طالبة في الدراسة الإعدادية بفرعيها العلمي والأدبي

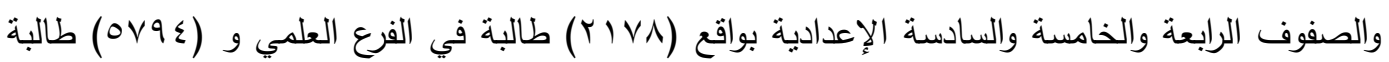

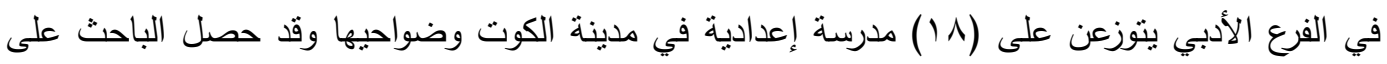

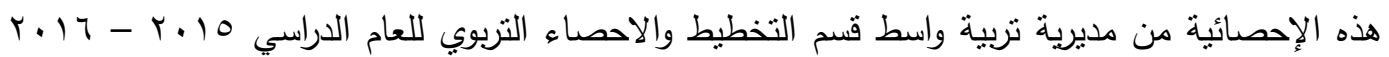

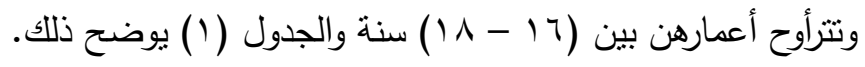

$$
\text { جدول (1) (1) (1) }
$$

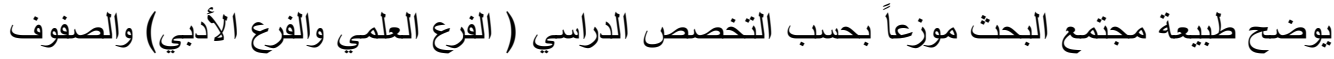

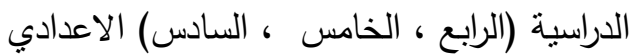

\begin{tabular}{|c|c|c|c|c|}
\hline المجموع & الصف السادس & الصف الخامس & الصف الرابع & الفرع الدراسي /لالصف الدراسي \\
\hline riru & 711 & 791 & VAr & الفرع العلمي \\
\hline OVa & צז & 1991 & 1974 & الفرع الألدبي \\
\hline Varr & rort & Y994 & $Y V \leq \varepsilon$ & المجموع \\
\hline
\end{tabular}


ثالثاً:عيّنة البحث:-اختيرت عيّنة البالغة(1/1) طالبة في الدراسة الإعدادية بفرعبها العلمي والأدبي

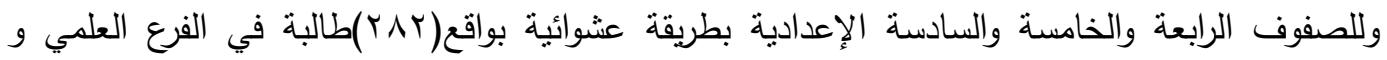

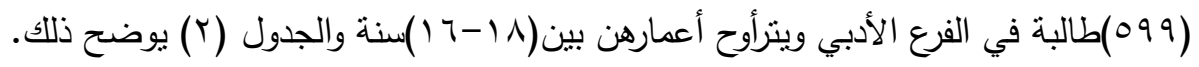

$$
\text { جدول(r) }
$$

يوضح طبيعة عيّنة البحث بحسب الفرع العلمي والأدبي والصفوف الدراسية

\begin{tabular}{|c|c|c|c|c|c|}
\hline \multicolumn{6}{|c|}{ (الرابع،الخامس،السادس) الاعدادي } \\
\hline نسبة عيّة البحث إلى & 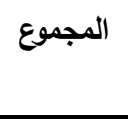 & الصفادس & الخامس & الرف & الفرع الدارسي/ الصف الدراسي \\
\hline$\% r r$ & rAr & $9 r$ & $9 r$ & $9 \wedge$ & الفرع العلمي \\
\hline$\% \curlyvee \wedge$ & 099 & 19. & r. & 199 & الفرع الأدبي \\
\hline$\% 1 \ldots$ & $\wedge \wedge 1$ & rAr & $r \cdot r$ & rqv & المجموع - المع \\
\hline
\end{tabular}

رابعاً: أدوات البحث:-لتحقيق اهداف البحث الحالي قام الباحث بترجمة مقياس روميرو و

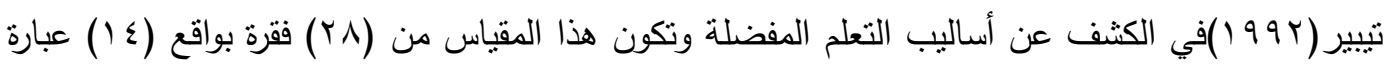

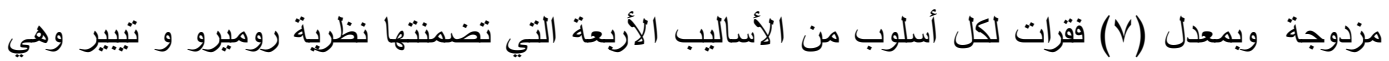

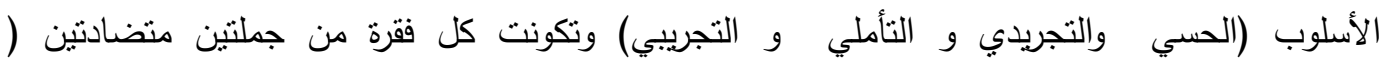
متعاكستين) (ثنائية القطب) تقيس أحدى الجملنين أحد أساليب التعلم منل الأسلوب الحسي وتقيس الجملة

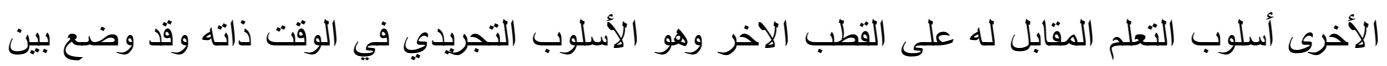

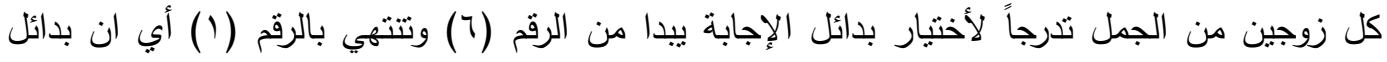

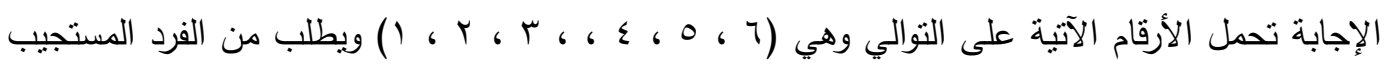

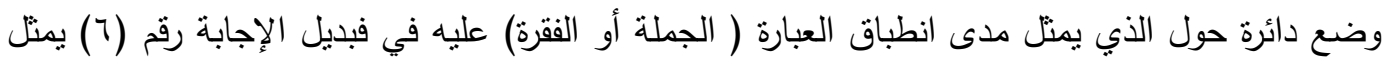

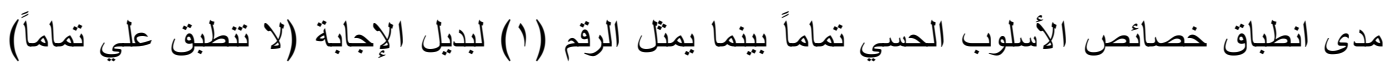

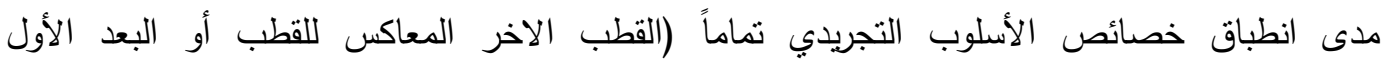

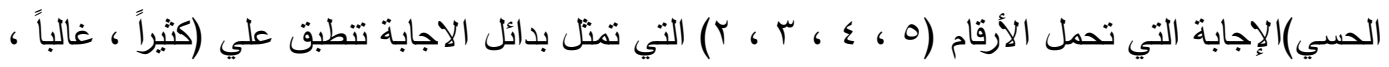

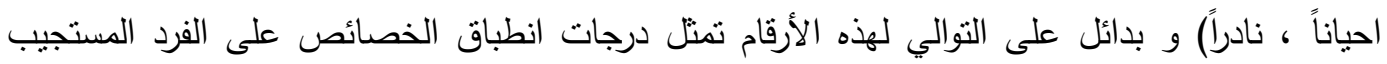

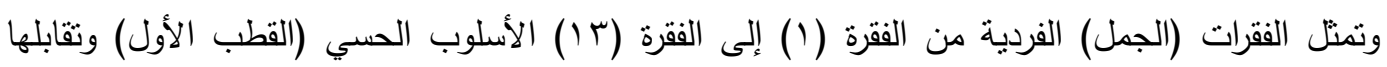


فقرات (جمل) تمثل الأسلوب التجريدي (القطب الثاني أو القطب الاخر المعاكس له).وتمثل الفقرات الزوجية

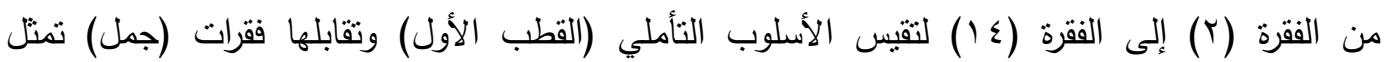

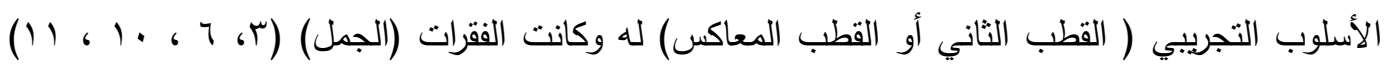
معكوسة في عملية تصحيح هذا المقياس ويقصد بتصحيح المقياس كيفية الحصول على الدرجة الكلية

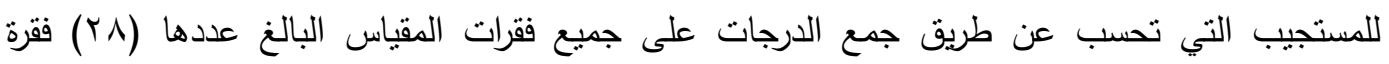
وقام(روميرو وتيبير)بأجراء تحليل عاملي لفقرات هذا المقياس إذا طبق على على عيّنة عشوائية مكونة

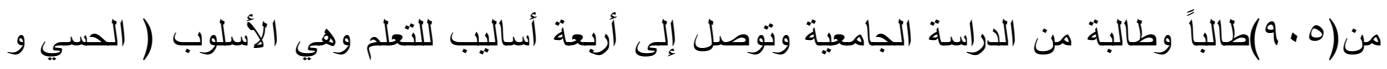

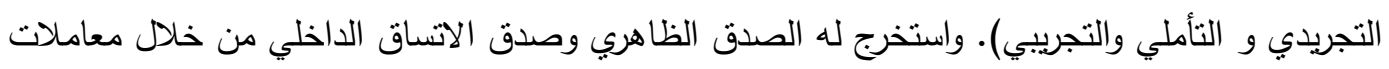

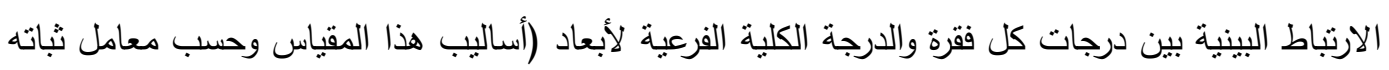

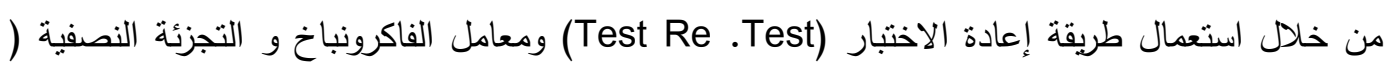
الفقرات الفردية والزوجية).

Validity صدق الترجمة: - مات

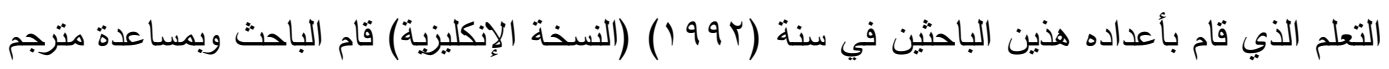

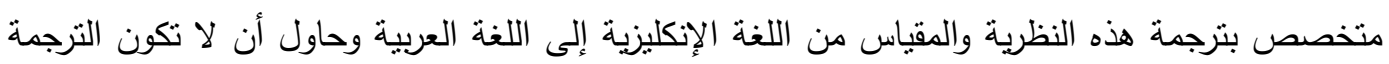

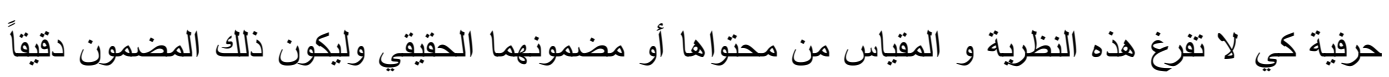

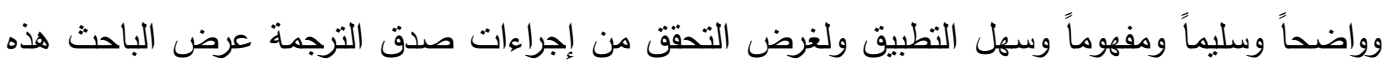

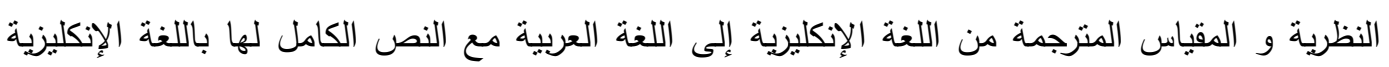

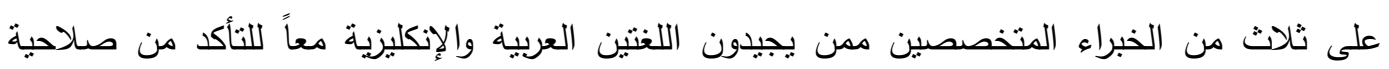
ترجمتها. وبعد الاخذ بالآراء المقترحة من هؤلاء الخبراء الثلاثة تم تعديل صياغة بعض التهن الفقرات (الجمل )

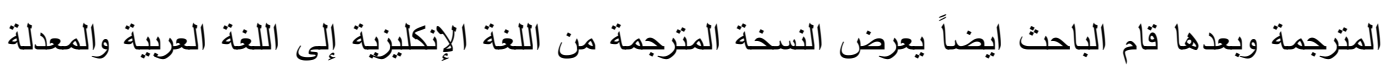

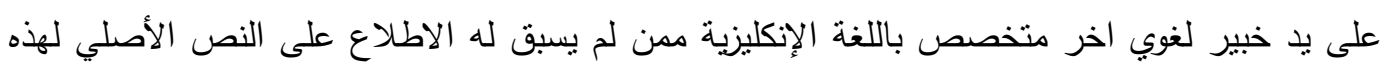

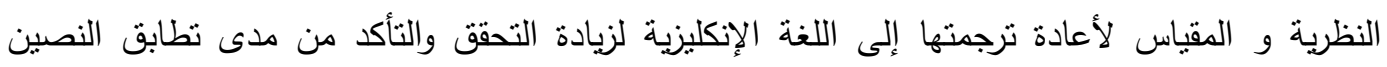

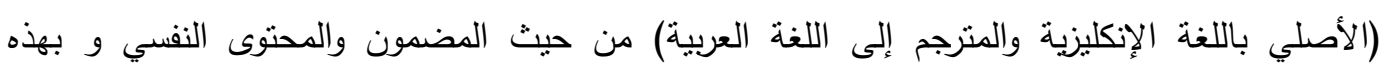

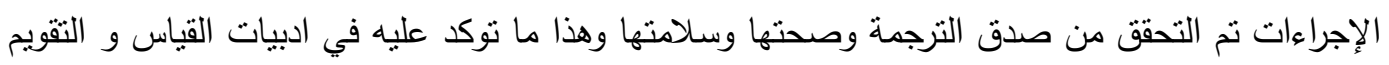

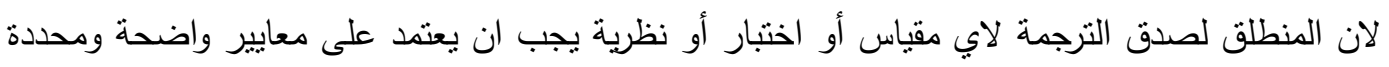

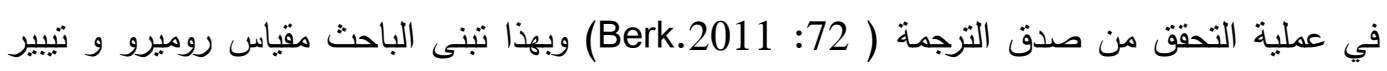

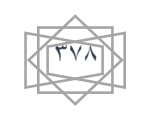


1991 لأساليب التعلم التي تم تعريبه و تكييفه للبيئة العراقية تمييداً لإيجاد الخصائص السايكومترية (الصدق والثبات) لفقراته وكالاتي :الصدق Validity :- لإيجاد صدق فقرات المقياس استعمل الباحث

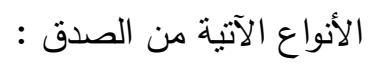

أ- الصدق الظاهري( Face Validity) تحقق هذا النوع من الصدق من خلال عرض فقرات المقياس على مجموعة من الخبراء المختصين بالعلوم التربوية والنفسية الذين طلب منهم بيان رايهم في مدى منى هن

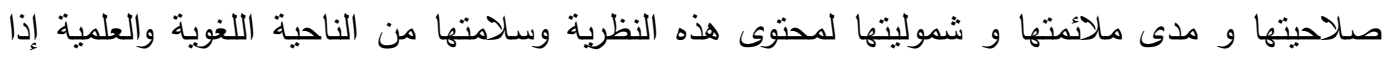

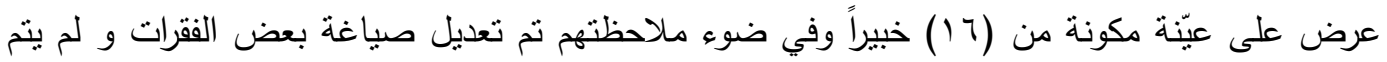

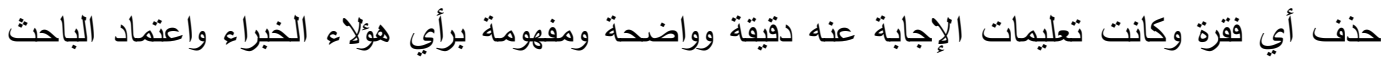

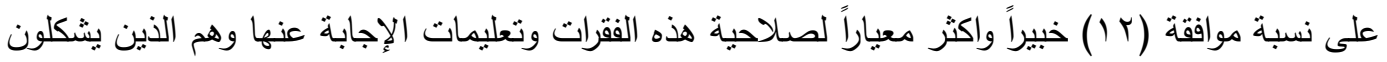

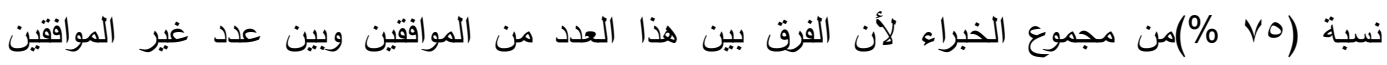

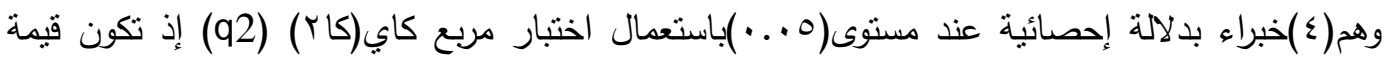

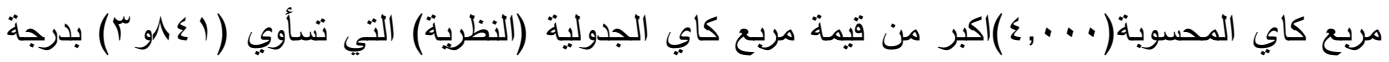

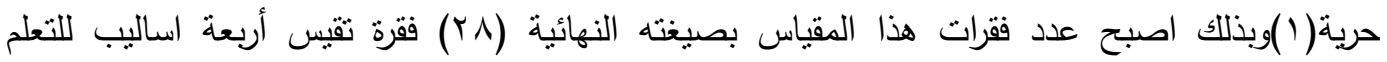

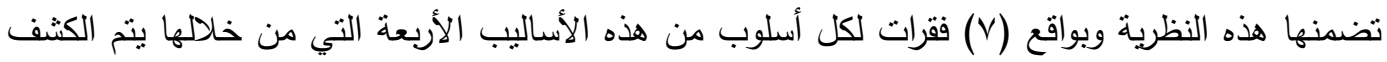
عن هذه الأساليب و التزم بها الباحث فعلاً في إجراءات ترجمة (تعريب) هذا المقياس وتكييفه للبيبئة

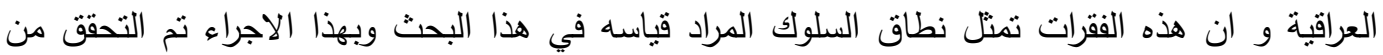

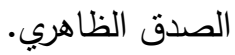

\section{Construct Validity) ب-صدق البناء (التركيب)}

ويعني قدرة المقياس على قياس سمة محددة أو مفهوماً نفسياً محدداً (البيلي وآخرون ، 1991 : ع وان هذا النوع من الصدق يتحقق من خلال الاتساق الداخلي للفقرات وقدرتها على التمييز بين الذين يمتلكون الصفة بدرجة ممتازة وبين الذين لايمتلكون الصفة (الضعاف في الصفة المراد

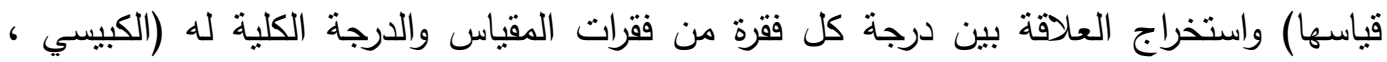

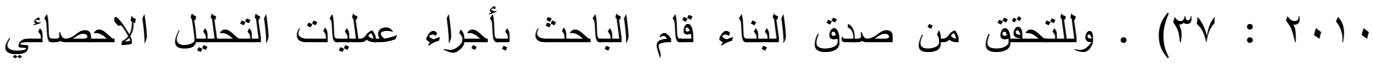
باستعمال الحقيبة الإحصائية للعلوم الاجتماعية (spss) لفقرات المقياس وذللك عن طريق 
ا-صدق الاتساق الااخلي من خلال معامل القوة التمييزية لفقرات الاختبار الذي تم تطبيقه على عينّة

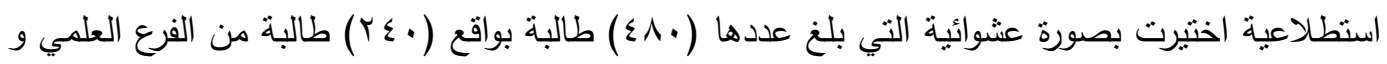

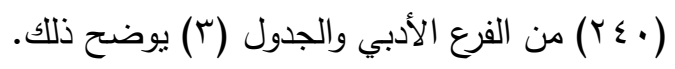

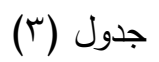

يوضح نوزيع عيّة التحليل الاحصائي لاستخراج القوة التمييزية لفقرات مقياس أساليب التعلم.

\begin{tabular}{|c|c|c|c|c|}
\hline 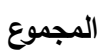 & الصف السادس & الصف الخامس & الصف الرابع & الفرع الدراسي / الصف الدراسي \\
\hline$r \leq$. & A. & A. & A. & الفرع العلمي \\
\hline$r \leq$. & $\Lambda$. & $\wedge$. & $\wedge$. & الفرع الأدبي \\
\hline$\leqslant \wedge$. & 19. & 14. & 17. & المجموع \\
\hline
\end{tabular}

إذا اثنارت اغلب ادبيات القياس النفسي إلى ان حجم العيّنة المناسب في عملية التحليل الاحصائي

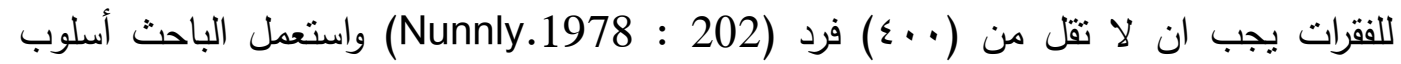

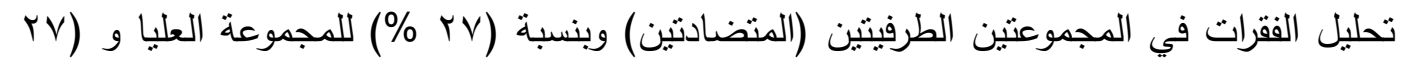

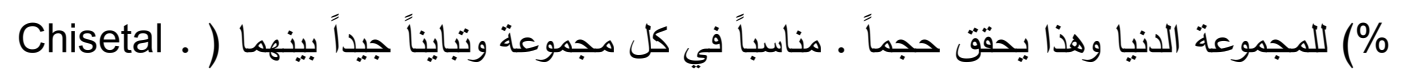

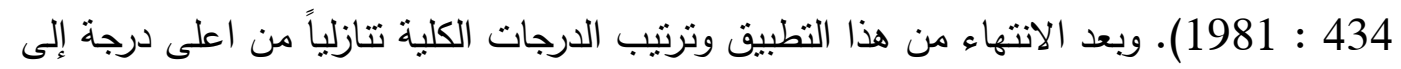

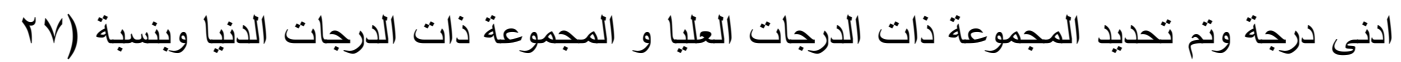

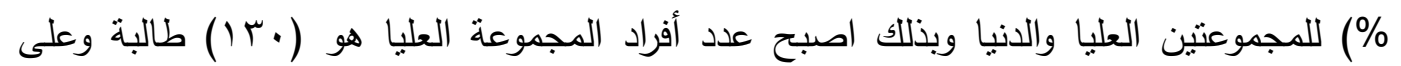

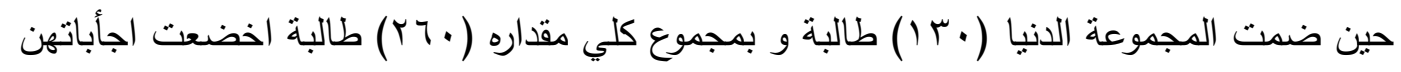

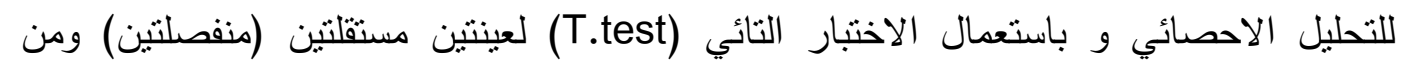
خلال مقارنة القيم التائية (T) المحسوبة والمذكورة في الجدول (ع) بالقيمة التائية (T) الجدولية

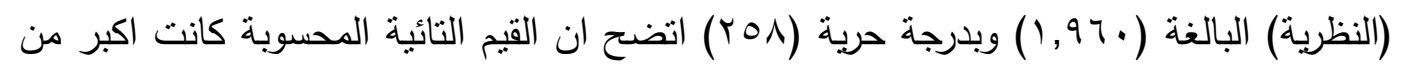

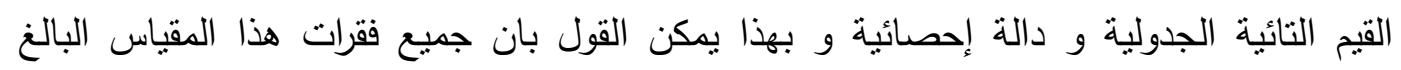
عددها (Y^)فقرة كانت مميزة و الجدول (ع) يوضح ذلك. 


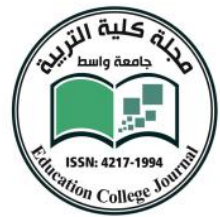

جدول (§)

يوضتح القوة التمييزية لفقرات مقياس أساليب التعلم

\begin{tabular}{|c|c|c|c|c|c|c|c|c|}
\hline \multirow{2}{*}{ الإحصائية(ه . , • ) مستوى الدلالة } & \multirow{2}{*}{ الرجة } & \multirow{2}{*}{$\begin{array}{c}\text { الجدولية } \\
\text { (T) }\end{array}$} & \multirow{2}{*}{ القيمة (T) } & \multicolumn{2}{|c|}{ 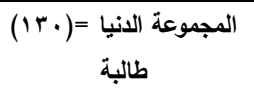 } & \multicolumn{2}{|c|}{ 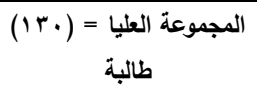 } & \multirow{2}{*}{$ت$} \\
\hline & & & & الانعراف & الحستوبط المبط & الانحراف & الحسابي & \\
\hline دالة إحصائيًا & ros & $1,97$. & $9, \leqslant$ Y & $\cdot, \wedge \vee 1$ & Y,VHI & $\cdot, r \leq r$ & $r, v i r$ & 1 \\
\hline دالة إحصائيًا & $r \otimes \Lambda$ & $1,97$. & $q, \cdot r_{1}$ & $1,0 \leq 1$ & ห,รฯч & $\cdot, 0 \leq$. & $r, \uparrow \wedge 0$ & r \\
\hline دالة إحصائيًا & $r \otimes \Lambda$ & $1,97$. & $0,90 r$ & $\cdot, \wedge \vee \leq$ & $r, \leqslant \circ r$ & $\cdot, r u$ & $r, q \circ r$ & $r$ \\
\hline دالة إحصائيًا & ros & $1,97$. & $V, \varepsilon r r$ & $1, \cdot \leq$ & $r, v \circ q$ & סזוז, . & ים & $\varepsilon$ \\
\hline دالة إحصائيًا & $r \otimes 1$ & $1,97$. & $0, v 00$ & I, & $r, q \wedge 1$ &., 004 & $r, r \leqslant q$ & 0 \\
\hline دالة إحصائيًا & ror & $1,97$. & $r, v r_{1}$ & $1,10 \leqslant$ & $r, 111$ & $1, r 10$ & r,vir & 7 \\
\hline دالة إحصائيًا & ros & 1,97 & 8,191 & $1,1 r 9$ & r,qVY &., 7.1 & $r, v \leq$. & $\mathrm{v}$ \\
\hline دالة إحصائيًا & ros & $1,97$. & V,Air & $\cdot, 9 \wedge 9$ & $r, . \leq 4$ & $\cdot, \leqslant 00$ & $r, \wedge v$. & $\wedge$ \\
\hline دالة إحصائيًا & ros & $1,97$. & $9,9 \leq 9$ & $1, \cdot v_{1}$ & r,OYA & $\cdot, 4$ & $r, v \cdot r$ & 9 \\
\hline دالة إحصائيًا & rol & 1,94 & $\varepsilon, \varepsilon \cdot V$ & $1,1 \cdot r$ & r,r,r & $1, \cdot r V$ & $r, q \vee r$ & 1. \\
\hline دالة إحصائيًا & ros & 1,94 & $9, .40$ &., $9 \vee$. & r,qor & ., $\leqslant 1 \%$ & $r, \wedge v$. & 11 \\
\hline دالة إحصائيًا & $r \otimes \lambda$ & 1,99 & $0,01 \mathrm{~V}$ & $1,1 Y \wedge$ & $r, \wedge \leq r$ & $\cdot, V Y V$ & $r, 004$ & ir \\
\hline دالة إحصائيًا & ron & 1,94 & $\Lambda, 7 \varphi_{0}$ & .,94. & Y,YYY &., $7 \leqslant 1$ & $r, v \cdot r$ & ir \\
\hline دالة إحصائيًا & ros & 1,94 & 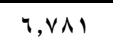 & $\cdot, 9 \vee 4$ & $r, Y i r$ & $\cdot, \varepsilon \cdot \wedge$ & $r, \wedge 9 \wedge$ & $1 \varepsilon$ \\
\hline دالة إحصائيًا & $r \otimes \Lambda$ & $1,99$. & $0, Y \wedge 1$ & $1,19 \mathrm{~V}$ & $r, Y r$. & $\cdot, \wedge 9 \leq$ & $r, r v q$ & 10 \\
\hline دالة إحصائيًا & $r \otimes \lambda$ & 1,99 & $\{, 190$ & $1, \ldots 1$ & $r, 7 q \leq$ & $\cdot, \wedge \leq 4$ & r,YYr & 17 \\
\hline دالة إحصائيًا & $r \otimes R$ & $1,97$. & $r, \leqslant \uparrow \wedge$ & 1,117 & $r, r r$. & $1, \cdot r r$ & $r, q \wedge 1$ & iv \\
\hline دالة إحصائيًا & $r \otimes \Lambda$ & $1,97$. & \&, \& & $1, I V r$ & $r, \wedge r r$ &., 749 & $r, \leqslant r_{0}$ & 11 \\
\hline دالة إحصائيًا & $r \otimes \Lambda$ & 1,97 & $\varepsilon, .9$. & 1,171 & r, INo & $\cdot, 7 v$. & $r, v i r$ & 19 \\
\hline دالة إحصائيًا & ror & $1,97$. & $v, 0 V_{1}$ & $1,1 r \varepsilon$ & Y,VYY & $\cdot$, , $\vee \wedge$ & $r, \uparrow \wedge 0$ & $r$. \\
\hline دالة إحصائيًا & ros & 1,94 & גזוד & $1,|r|$ & $r, T \leqslant \Lambda$ & $\cdot, \wedge \cdot \wedge$ & $r, q \wedge 1$ & rI \\
\hline دالة إحصائيًا & $r \otimes \Lambda$ & 1,94 & $r, 111$ & $1, .17$ & r,INo & $\cdot, 0 \wedge \leq$ & $r, v \cdot r$ & $r r$ \\
\hline دالة إحصائيًا & $r \circ \Lambda$ & 1,94 & R & $1,19 \leq$ & $r, v \vee V$ & $1, . \times 1$ & $r, 1 \mu \Lambda$ & $r r$ \\
\hline دالة إحصائيًا & $r \otimes \Lambda$ & 1,97 & $7, \leqslant 9$. & $1, \cdot v V$ & $r, \Lambda I \leq$ &., $7 \wedge 1$ & $r, 71)$ & $r \varepsilon$ \\
\hline دالة إحصائيًا & $r \otimes \Lambda$ & $1,97$. & $\varepsilon, \wedge r \wedge$ &., $9 r r$ & $r, \varepsilon q$. & $\cdot, r \leqslant V$ & r,quo & ro \\
\hline دالة إحصائيًا & $r \otimes \Lambda$ & 1,94 & v,or. & $1,1 \leq V$ & r, ג & $\cdot, \vee 19$ & r,rr. & $r 4$ \\
\hline دالة إحصائيًا & ros & $1,97$. & $7, \leqslant 90$ & $1, .71$ & $r, \varepsilon \cdot V$ & .971 & $r, r . \theta$ & YV \\
\hline دالة إحصائيًا & $r \otimes 1$ & $1,97$. & $v, 0 V_{1}$ & $1,1 \leqslant r$ & r,VYr & $\cdot, 9 \vee \wedge$ & $r, r \wedge 0$ & rA \\
\hline
\end{tabular}


ץ-معاملات الارتباط بين درجة كل فقرة واللارجة الكلية الفرعية لأساليب مقياس (روميرو و

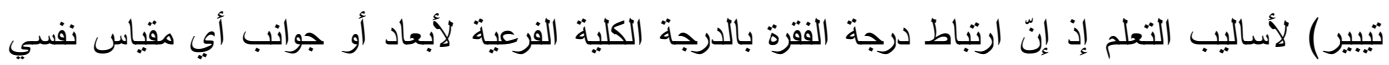

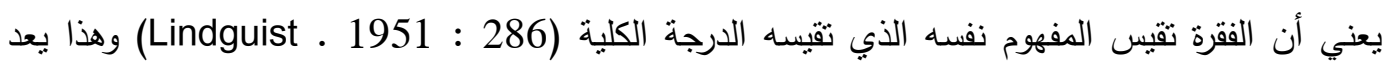
أحدى مؤشرات صدق البناء إذ حسبث معاملات الارتباط البينية باستعمال معادلة بيرسون (Pearson)

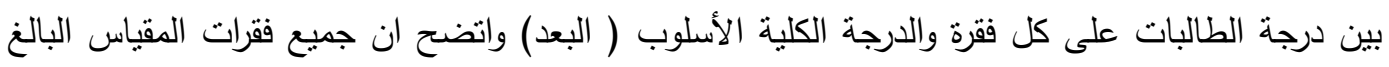

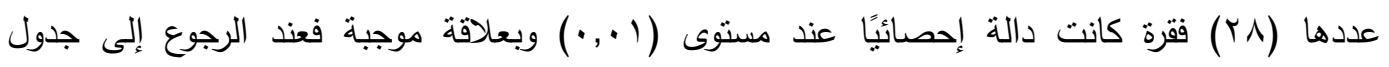

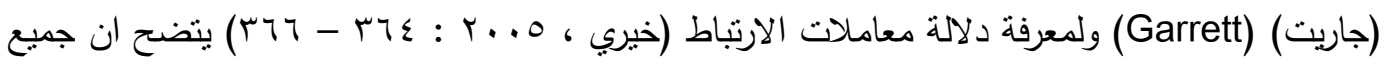

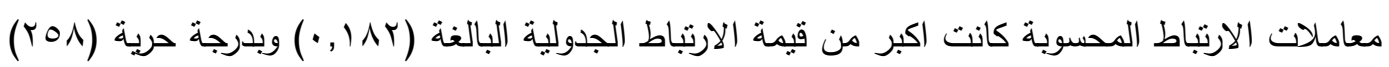

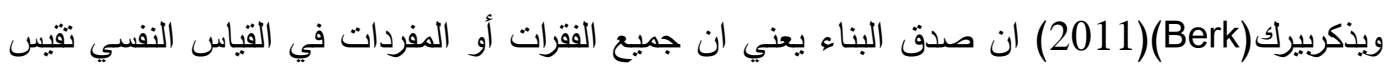

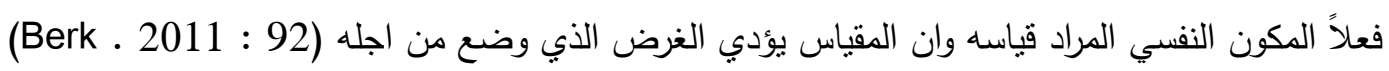

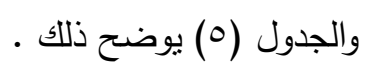

جدول (0)

يوضح معاملات الارتباط بين درجة الفقرة والدرجة الكلية الفرعية لأبعاد مقياس روميرو وتيبير لأساليب

\begin{tabular}{|c|c|c|c|c|c|c|c|}
\hline التجريبي قيمة الأسلوب & الفقرات & التأسلأسلوب & الفقرات & التجريدي قيمة الأسلوب & الفقرات & الحسي قيمة & الفقرات \\
\hline$\cdot, \wedge q$. & $\varepsilon$ & DTY,T & $r$ & $\cdot, \wedge \leq 7$ & $r$ & זAT, & 1 \\
\hline . VAT & $\wedge$ & - $\{$ \&AY & 7 &.,$V \leqslant 7$ & v & דצד, & 0 \\
\hline ., \&AV & rr & -,$\leqslant 9 \leqslant$ & 1. &., $0 \leqslant 7$ & 11 & •, AAV & 9 \\
\hline ., $\mathrm{V} \vee A$ & 17 & •, AAr & $1 \varepsilon$ & . हA & 10 & $\cdot, \lambda r)$ & ir \\
\hline$\cdot, 719$ & $r$. & . $71 \wedge 1$ & 11 & . हा। & 19 & . $\leq 47$. & IV \\
\hline., $0 \wedge \mathrm{V}$ & $r \varepsilon$ & .,OVT & $\overline{r r}$ &., $07 r$ & r & $\cdot, V 7 \Lambda$ & ri \\
\hline r & $r_{\Lambda}$ & ד1, & ry & .,00r & TV & ـ & ro \\
\hline
\end{tabular}


r-مصفوفة معاملات الارتباط البينية المقياس نم التحقق من صدق مقياس أساليب التعلم بإيجاد

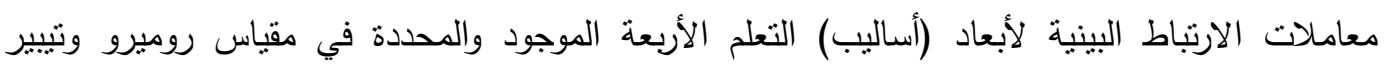

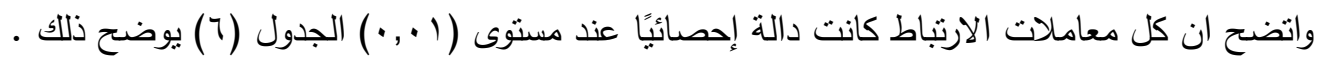

$$
\text { جدول (7) }
$$

يوضح مصفوفة معاملات الارتباط البينة لمقياس أساليب التعلم

\begin{tabular}{|c|c|c|c|c|}
\hline التجريبي & التأملي & التجريدي & الحسي & أسلوب التعلم \\
\hline$\cdot, \wedge \wedge 1$ &., $7 \wedge \wedge$ & .,人Tr & - & الحسي \\
\hline$\cdot, \wedge r$. & $\cdot, T \leq r$ & - & - & التجريدي \\
\hline • & - & - & - & التأملي \\
\hline- & - & - & - & التجريبي \\
\hline
\end{tabular}

الثبات : Reliability يعد الثبات من الخصائص المهمة لاي اختبار أو مقياس فالمقياس الثابت هو

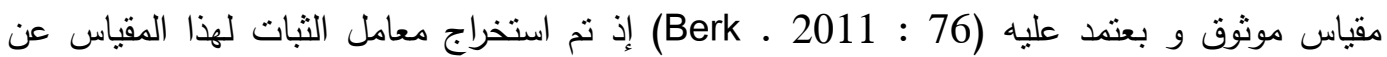

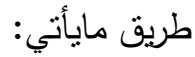

أ- طريقة الاختبار - إعادة الاختبار (Test. Re .Test) إذ طبق المقياس على عيّنة عشوائية مكونة من

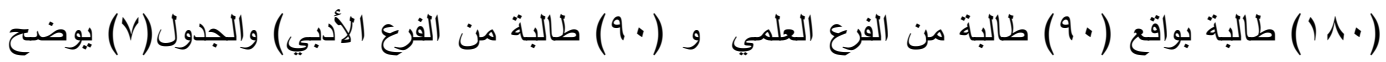
ذلك.

$$
\text { جدول (v) }
$$

\begin{tabular}{|c|c|c|c|c|c|}
\hline المجموع & الصف السادس & الصف الخامس & الصف الرابع & الفرع الدارسي/ الصف & $ت$ \\
\hline 9. & $r$. & r. & $r$. & الفرع العلمي & 1 \\
\hline 9. & $r$. & r. & $r$. & الفرع الأدبي & r \\
\hline $1 \lambda$. & 7. & 7. & 7. & الدجموع & \\
\hline
\end{tabular}

يوضح طبيعة توزيع عينّة الثبات تبعاً للفرع الدراسي و الصفوف الدراسية 
وبعد مرور أسبوعين اعيد تطبيق المقياس على العيّنة ذاتها ((إذ تعد هذه المدة مناسبة لمنل هذه المقاييس)(208) : Nunnully . 1978 وبعد الانتها من التطبيق تم حساب ثبات المقياس و ذلك عن طريق حساب درجات هذه العيّنة من التطبيق الأول و حساب درجات العيّنة نفسها في التطبيق الثاني و خضعت نتائج التطبيقين الأول و الثاني للتحليل الاحصائي وتم حساب معامل الارتباط (بيرسون) بين درجة هذين التطبيقين فبلغ معامل التبات (100, •) وهو معامل ارتباط جيد ومقبول مما يثنير إلى ان المقياس له استقرار ثابت عبر الزمن الذي يمكن الاعتماد عليه في ثبات المقياس. ب- معامل الفاكرونباخ (Cronbach's Alpha) إذ بلغ معامل ثبات المقياس (Y r, • ) ج- طريقة التجزئة النصفية Split half method ان يجاد معامل الثبات بطريقة التجزئة النصفية يتطلب تقسيم المقياس بعد إجابة المفحوصين عن فقراته إلى قسمين بحيث يشمل القسم الأول على الفقرات الفردية بينما يشمل القسم الثاني على الفقرات الزوجية وبعد ذلك يتم حساب معامل الثبات بين هذين القسمين أو الجزئين. إذ بلغ معامل الثبات باستعمال معادلة سيبرمان - برأون (Spearma - Brown Formula)

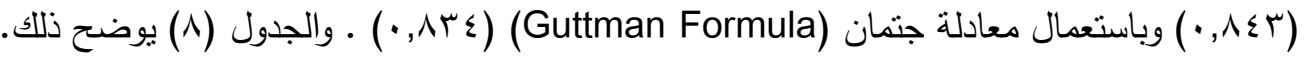

\section{جدول (^)}

يوضح قيم معاملات الثبات لمقياس روميرو و تيبير لأساليب التعلم باستعمال طريقة إعادة الاختبار و معادلة الفاكرونباخ وطريقة التجزئة النصفية

\begin{tabular}{|c|c|c|c|c|c|}
\hline \multicolumn{2}{|c|}{ طريقة التجزئة النصفية } & \multirow{2}{*}{ معامل الفاكرونباخ } & \multirow{2}{*}{ إعادة الاختبار } & \multirow{2}{*}{ أسلوب التعلم } & \multirow{2}{*}{ ت } \\
\hline جتمان & سبيرمان - برأون & & & & \\
\hline$\cdot, \wedge r \leq$ & $\cdot, \wedge \leqslant r$ & $\cdot, \wedge \leq 1$ & $\cdot, \wedge \uparrow \wedge$ & الحسي & 1 \\
\hline$\cdot, \wedge \uparrow \wedge$ & $\cdot$, Атт & $\cdot, \wedge Y$ & $\cdot, \wedge \uparrow \wedge$ & التجريدي & r \\
\hline •,AKr & •,人Tr & $\cdot, \lambda \mid r$ & •,AYr & التأملي & $r$ \\
\hline •,AKr & $\cdot, \Lambda \cdot r$ & $\cdot, \wedge) \leq$ & $\cdot, \Lambda \cdot r$ & التجريبي & $\varepsilon$ \\
\hline •,ATE & $\cdot, \wedge \leqslant \Gamma$ & $\cdot, A Y Y$ & $\cdot, \wedge 00$ & ككل & \\
\hline
\end{tabular}


وبعد التحقق من الخصائص السايكومترية كالصدق و الثبات لهذا المقياس الذي اصبح بصيغته النهائية

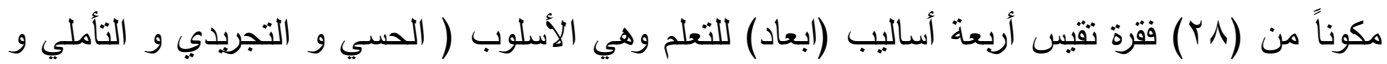

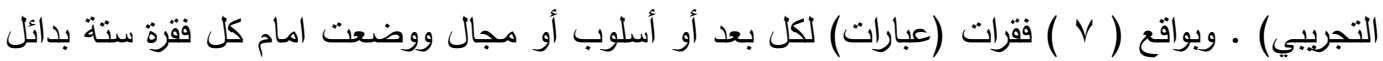

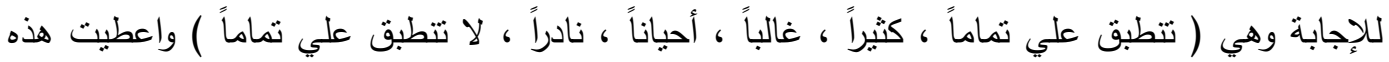

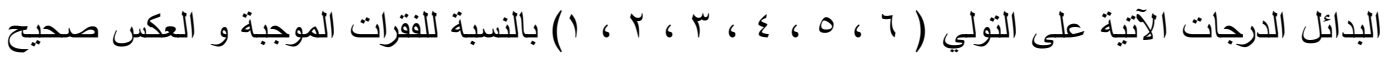

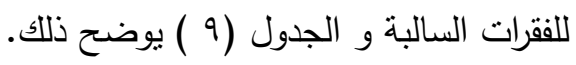

$$
\text { جدول (9) }
$$

يوضح توزيع الأوزان على بدائل الإجابة لمقياس روميرو و تيبير لأساليب التعلم

\begin{tabular}{|c|c|c|c|c|c|c|}
\hline لا تتطبق علي تماماً & 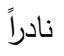 & 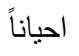 & غالباً & 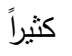 & تتطبق علي تماماً & الفقرات \\
\hline 1 & r & $r$ & $\varepsilon$ & 。 & 7 & الإيجايية \\
\hline 1 & 。 & $\varepsilon$ & $r$ & r & 1 & السلبية \\
\hline
\end{tabular}

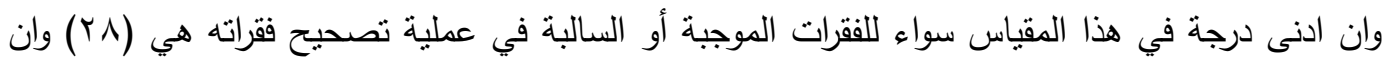

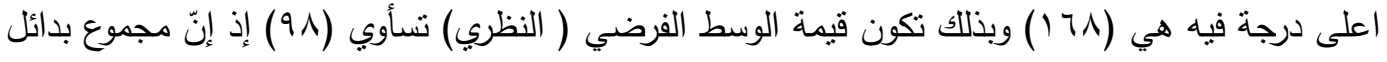

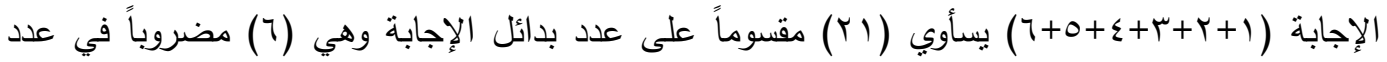

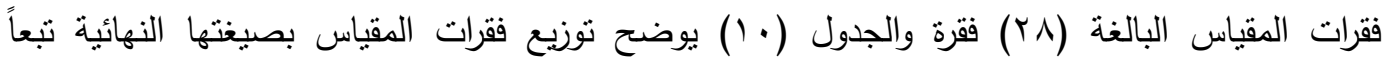
لاساليب التعلم الأربعة التي تضمنتها هذا المقياس.

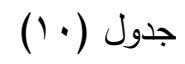

\begin{tabular}{|c|c|c|c|c|c|}
\hline 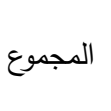 & السام الفقرات & ارقام الفقرات الموجبة & تسلسل بعد التعليم و اتجاهه & أسلوب التعلم & 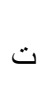 \\
\hline v & $r 1,0$ & $\begin{array}{c}\text { a } 1 v ، 1 r ، 9,1 \\
\text { ro }\end{array}$ & القطب-البعد الأول & الحسي & 1 \\
\hline v & r , V & $\begin{array}{c}6 r 9,10,11 ، r \\
r v\end{array}$ & المعاكس المضاد اللبعد الأول القبان & التجريدي & r \\
\hline
\end{tabular}

يوضح توزيع فقرات مقياس روميرو و تنيير لأساليب التعلم بصيغتها النهائية 


\begin{tabular}{|c|c|c|c|c|c|}
\hline \multicolumn{4}{|c|}{ العـــــــد الرابع والعشرون } & \multicolumn{2}{|c|}{ مجلـــــة كليـــــة التربيــــة } \\
\hline 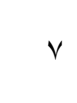 & $11 \cdot 1$. & $\begin{array}{c}6 r \% 1 \leq 696 r \\
r q\end{array}$ & القطب -البعد الثالث & 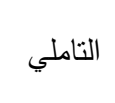 & $r$ \\
\hline v & $r \cdot a 1 r$ & $\frac{6}{r \wedge}$ & المضاد -المعاكس -البعد الرابع & التجريبي & $\varepsilon$ \\
\hline rA & $\wedge$ & $r \cdot$ & \multicolumn{3}{|c|}{ المجموع الكلي لفقرات المقياس بصيغته النهائية } \\
\hline
\end{tabular}

ومراعا لشروط النشر في المجلات العلمية التخصصية المحكمة و لاسيما بخصوص عدد صفحات البحث وحفاظاً على حقوق الباحث وعدم سرقتها أو استغلال المقياس يعتذر الباحث للسادة الخبراء المقومين المحترمين والقراء الأعزاء عن وضعه في ملاحق هذا البحث و يمكن الحصول عليه من خلال الاتصال المباشر بالباحث أو مراسلته على عنوانه الوظيفي المذكور في هذه المجلة. خامساً : - الوبائل الإحصائية:- استعمل الباحث الحقيبة الإحصائية للعلوم الاجتماعية (spss) في التحقق من صدق وثبات أداة البحث وفي عرض ومناقثة نتائج هذا البحث ومن أبرز هذه الوسائل هي ما يأتي:-

1- معادلة مربع كاي لإيجاد الصدق الظاهري (صدق الخبراء) لهذا المقياس. Test. Re ) معامل الارتباط بيرسون لإيجاد صدق المقياس و معامل ثباته بطريقة إعادة الاختبار $\cdot($. Test س- معادلة الفاكرونباخ و التجزئة النصفية (معادلة سبيرمان - برأون و معادلة جتمان) لايجاد معامل ثبات هذا المقياس

ع - الاختبار التائي (T.test) لعيّنة واحدة ولعينتين مستقلتين (منفصلتين) في عرض النتائج و مناقثتها. ه - تحليل التباين الأحادي (القيمة الفائية F) لاختبار صحة الفرضية ولئية الثنانية. 


\section{الفصل الرابع}

\section{عرض النتائج ومناقشتها}

أولاً :- عرض النتائج ومناقشتها:-لتحقيق الهدف الأول الذي ينص على ما يأتي " التعرف على أساليب التعلم المفضلة في ضوء نظرية روميرو و تنيير لدى طالبات مرحلة الدراسة الإعدادية في مركز

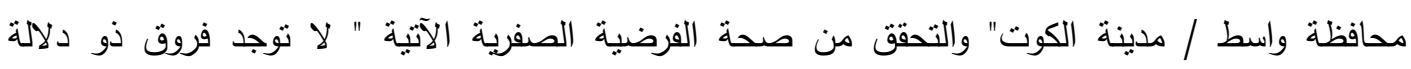

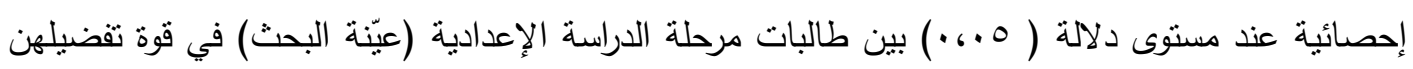

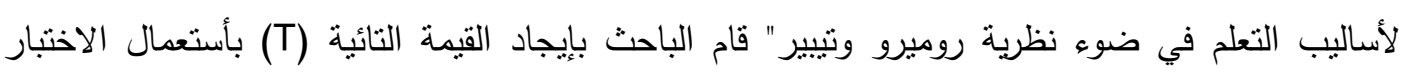

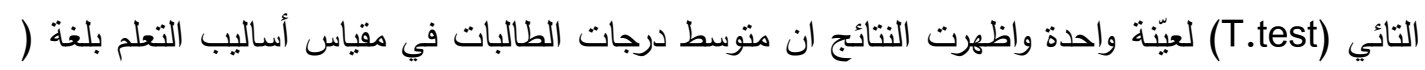

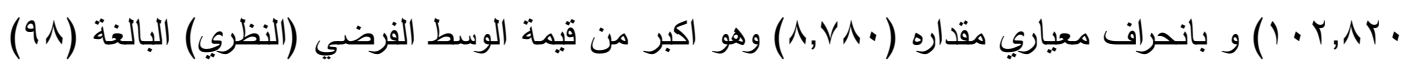

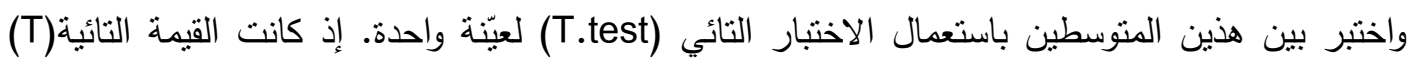

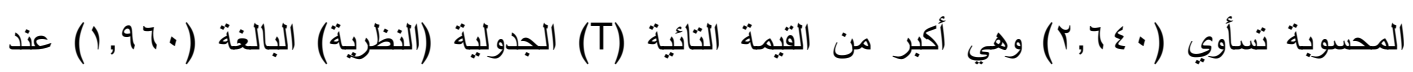

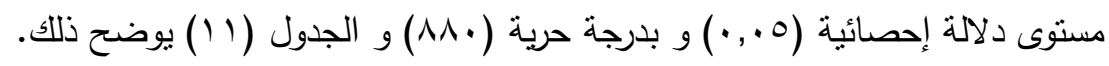

جدول (1) (1) (1) (1)

يوضح نتائج الاختبار التائي (T) لعيّنة واحدة لتحقيق الهدف الأول في هذا البحث

\begin{tabular}{|c|c|c|c|c|c|c|c|}
\hline مستوى الدلاية & \multicolumn{2}{|c|}{ القيمة التائية (T) } & \multirow{2}{*}{ الدرية } & \multirow{2}{*}{ الفرضي } & \multirow{2}{*}{ المعياري } & \multirow{2}{*}{ الحسابي } & \multirow[b]{2}{*}{ العيّة } \\
\hline 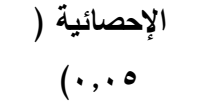 & الجدولية & المحسوية & & & & & \\
\hline يوجد فرق لصالحة إحصائًاً & $1,94$. & $r, T \leqslant$. & $\wedge \wedge$. & $9 \wedge$ & $\wedge, \vee \wedge$. & I. Y,AY. & ANI \\
\hline
\end{tabular}

وهذا يدل على وجود فروق ذوات دلالة إحصائية في أساليب التعلم بين طالبات مرحلة الدراسة الإعدادية

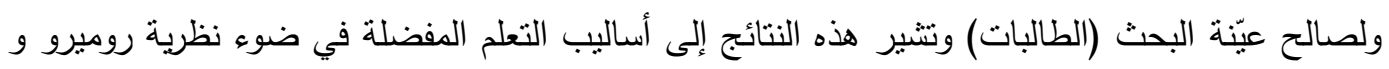

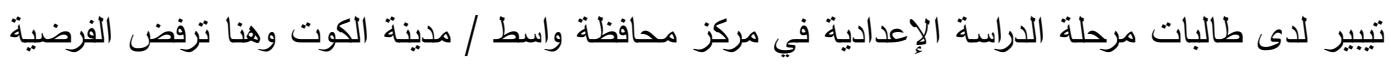

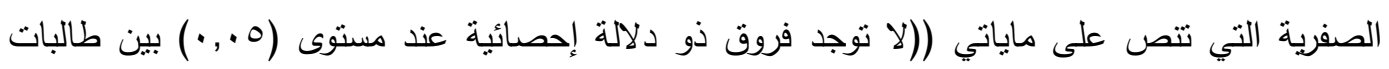

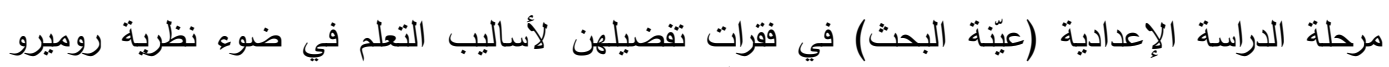


وتنيير)) وتقبل الفرضية البديلة التي تتص على ماياتي (( توجد فروق ذوات دلالة إحصائية عند مستوى

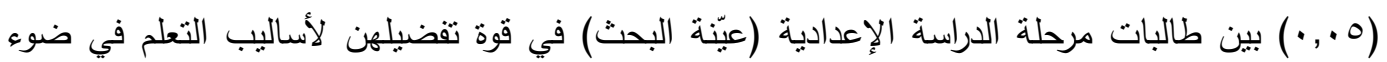
نظرية روميرو و تنيير)) ويتضح هذا من خلال اختلاف المتوسطات الحسابية لأساليب التعلم المفضلة فقد

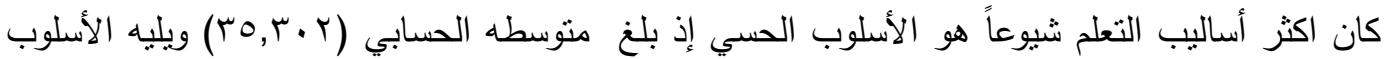
التأملي بمتوسط حسابي مقداره ( . . (Y0, ويتضح ان الفرق كبير بين هذين الاسلوبين وجاء الأسلوب التجريدي بالمرتبة الثالثة إذ حصل على متوسط حسابي مقداره (Y Y, Y Y) على حين جاء الأسلوب التجريبي بالمرتبة الرابعة (الأخيرة) إذ حصل على متوسط حسابي مقاره (T • I, I ) والجدول (Y I) يوضح

جدول (Y)

يوضح قيم المتوسطات الحسابية لاساليب التعلم

\begin{tabular}{|c|c|c|c|c|c|}
\hline المرتبة & قيم الانحراف المعياري & قيم التباين & قيم المتوسطات الحسابية & أساليب التعلم & ت \\
\hline الأولى & r,rדr & $1 \cdot, 7 \leq$ & $r 0, r \cdot r$ & الحسي & 1 \\
\hline الثانية & $r, r) \leq$ & 0, ros & $r \varepsilon, 11 T$ & التجريدي & r \\
\hline الثالثة & $r, I T \leq$ & $\varepsilon, 011$ & $r_{0,1} \ldots$ & التاملي & $r$ \\
\hline الرابعة & $1,1 \cdot r$ & $1, Y \backslash \leq$ & $1 \Lambda, r \cdot T$ & التجريدي & $\varepsilon$ \\
\hline l & $\wedge . \vee \wedge$. & r $1, v 19$ & 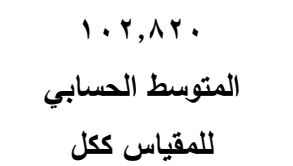 & \multicolumn{2}{|c|}{ المجموع } \\
\hline
\end{tabular}

وان هذه النتائج مرنبة بصورة تتازلية من اعلى قيمة منوسط حسابي إلى ادنى قيمة منوسط حسابي لهذه الأساليب وان هذه النتيجة تدل على وجود اختلاف كبير بين طالبات مرحلة الدراسة الإعدادية (عيّنة البحث) في قوة تفضيلهن لأساليب التعلم في ضوء نظرية روميرو و تيبير وقد يعزى سبب ذلك إلى طبيعة مرحلة الدراسة الإعدادية واختلاف الصف الدراسي و التخصص (الفرع) الدراسي إذ نشير نتائج دراسة (2013 , Koyes) (Koyes , 2013 : 89) • وقد يعزو الباحث هذه النتيجة ايضاً إلى وجود فروق وتباينات كبيرة في بعد

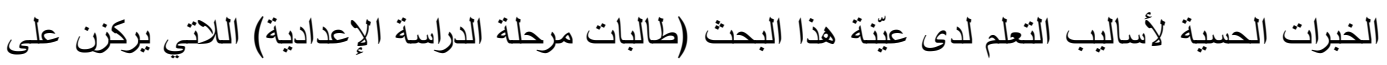
الأسلوب الحسي في التعلم بالدرجة الأولى و لاسيما طالبات الفرع الأدبي ويله الأسلوب التأملي و لاسيما

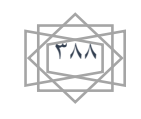




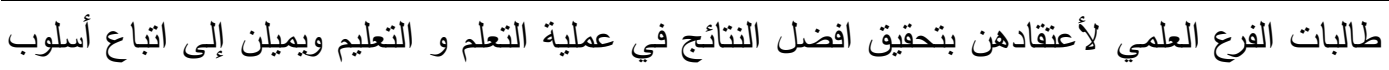
المعرفة (الحفظ و الاستظهار الالي) دون تحقيق مهارات الفهم و التطبيق و التحليل و التركيب و التقويم

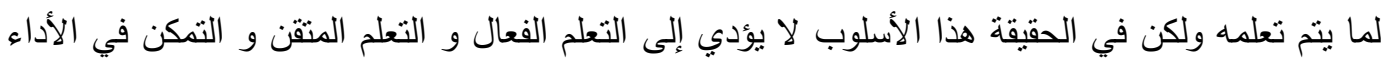

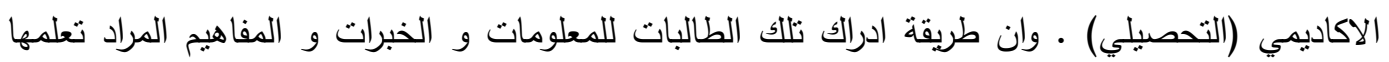

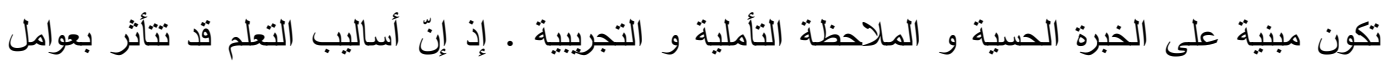
العمر الزمني و العمر العقلي للطالبات اللاتي يتبعن استراتيجيات اكثر مرونة و مستوى أساليب عميقة في

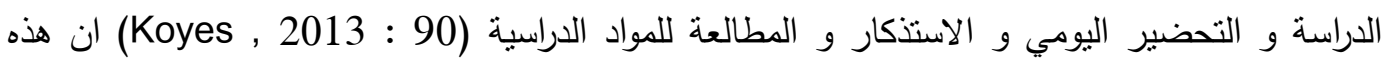

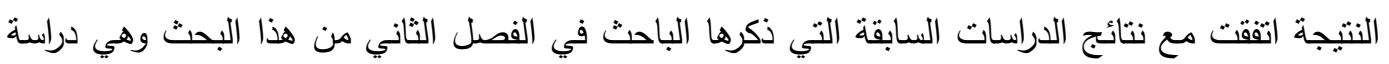

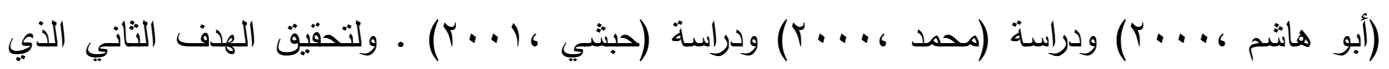

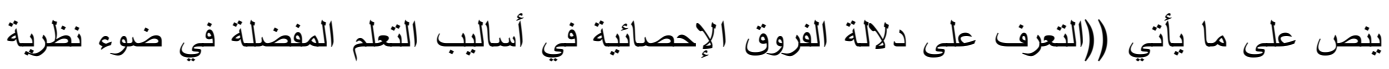

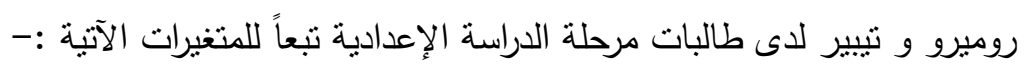

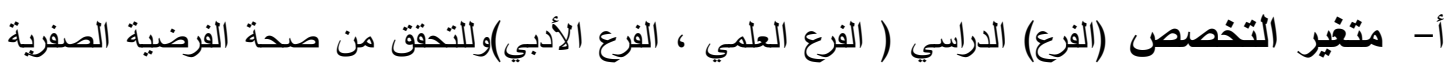

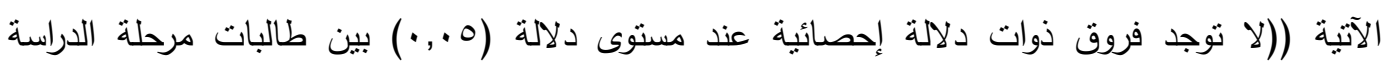

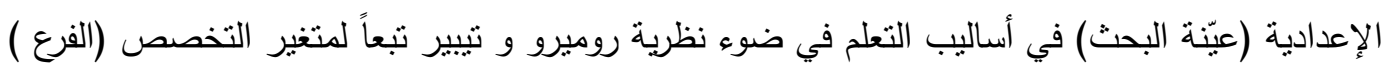

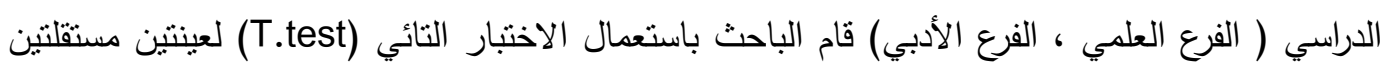

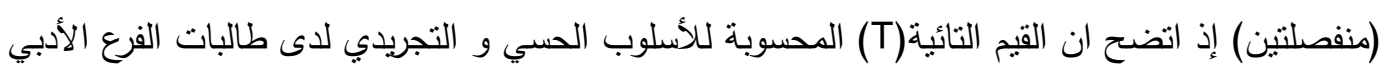

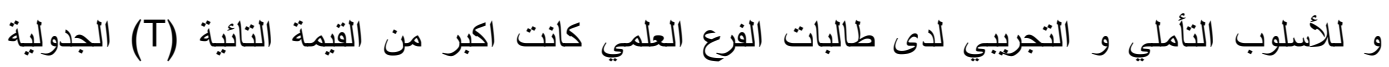

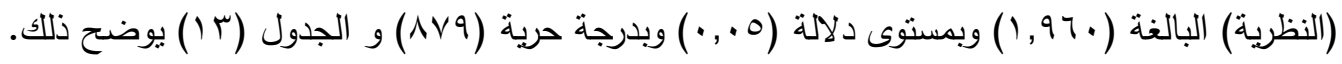


جدول (ril)

يوضح نتائج الاختبار النائي(T) لعينتين مستقلنين لمعرفة دلالة الفروق الإحصائية في أساليب التعلم تبعاً

\begin{tabular}{|c|c|c|c|c|c|c|c|c|c|}
\hline مستوى | مستوى & $(T)$ & القيمة & & $099=$ & الفرع الا & YAY $=$ & الفرع العل العل الفر & & \\
\hline لمعرفة اتجاه & الجدولية & المحسوية & لدرجة & المعياري & الحسابي & المعارياف & المتوسط الحسابي & أستليب & $ت$ \\
\hline لدالد الحصائية الفرق & 1,94. & r, ivo & AVq & $r, A V_{0}$ & $r Q, Y r$. & $r$. & ro, Irr & الحسي & 1 \\
\hline 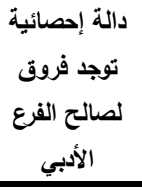 & 1,94 & r,tro & Ava & l,r. & $\lceil\wedge, 1 \wedge$. & $r, \leqslant 40$ & $r 0,114$ & التجريدي & r \\
\hline 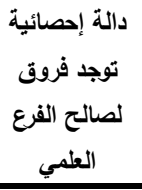 & 1,94 & r.,91. & Ava & $1,11$. & iv, rvo & ו ג & ri, ror & التأملي & $r$ \\
\hline 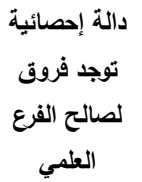 & $1,94$. & r,097 & AVq & $1, \ldots r$ & 16,444 & $1,1, r$ & IV,rer. & التجريبي & 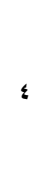 \\
\hline
\end{tabular}

لمتغير التخصص (الفرع) الدراسي وتحقيقاً للهدف الثاني من هذا البحث

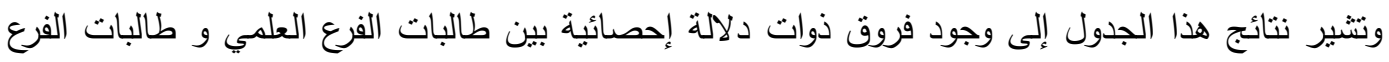
الأدبي في أساليب التعلم وهي أسلوب الحسي والتجريدي لصالح الفرع الأدبي والأسلوب التأملي والتجريبي

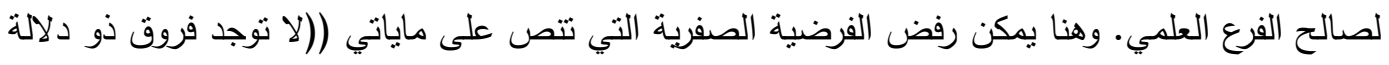

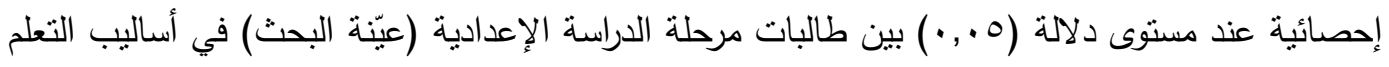
في ضوء نظرية روميرو و تيبير تبعاً لتنغير التخصص (الفرع) الدراسي (الفرع العلمي ، الفرع الأدبي) وتقبل الفرضية البديلة التي تتص على ماياتي (( توجد فروق إحصائية ذوات دلائلة عند مستوى دلالة

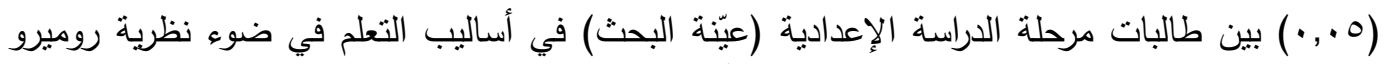


وتيبير تبعاً لمتغير التخصص (الفرع) الدراسي (الفرع العلمي ، الفرع الأدبي) ويعزو الباحث هذه النتيجة

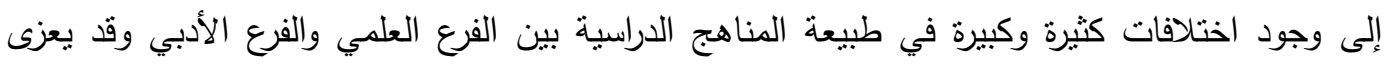

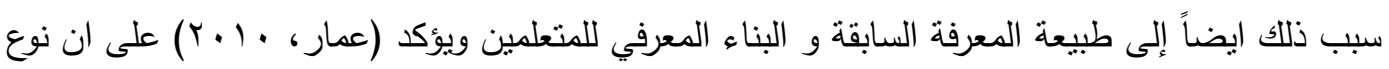

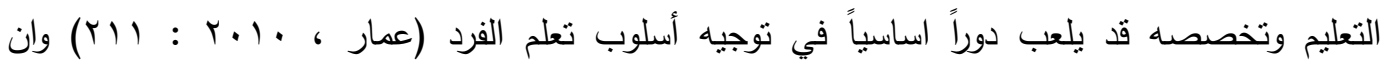

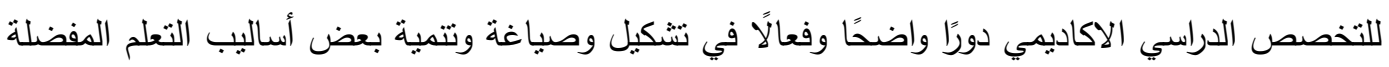

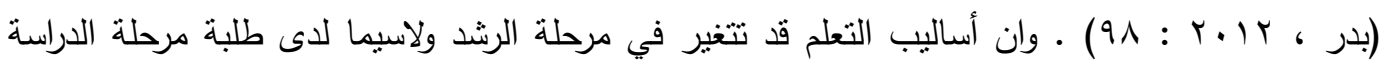

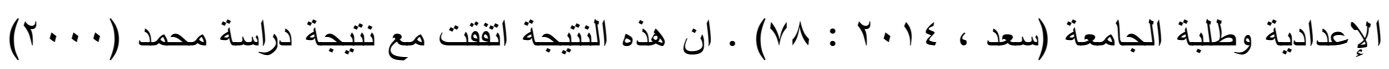

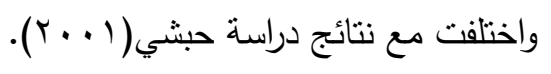

ب- متغير الصف الاراسي (الصف الرابع ، الصف الخامس ، الصف الساد) الاعدادي وللتحقق من

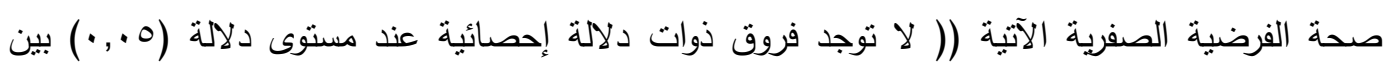

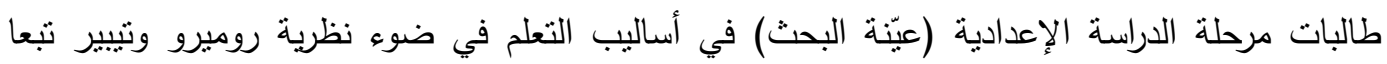
لمتغير الصف الدراسي (الصف الرابع ، الصف الخامس ، الصف الصف السادس) الاعدادي )) استعمل الباحث

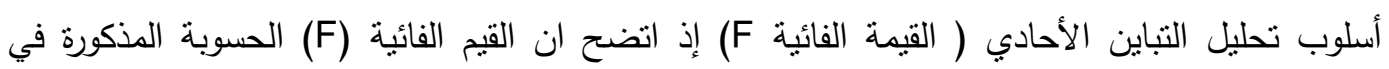

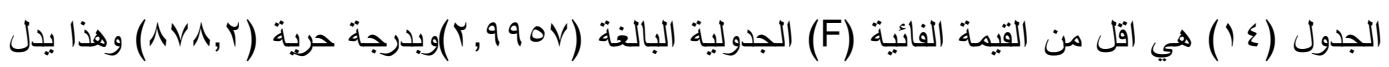

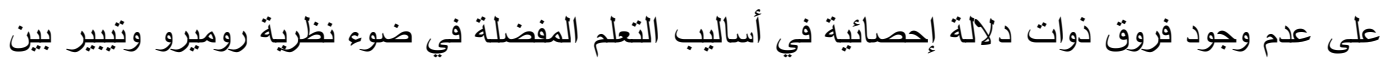

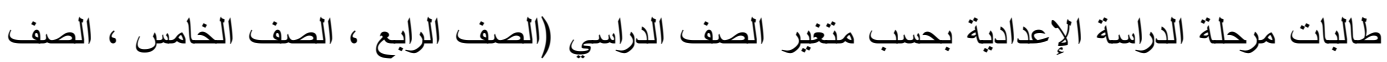

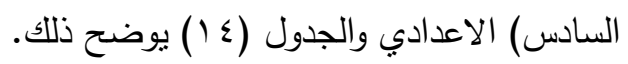




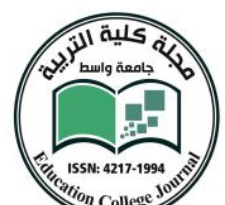

جدول( ) (1) (a)

مجلــــة كليـــــة التربيــــة

يوضح نتائج الاختبار الفائي (F.test) لمعرفة دلالة الفرروق الإحصائية في أساليب التعلم تبعاً لمتغير الصف الدراسي ( الرابع ، الخامس ، السادس) الاعدادي

\begin{tabular}{|c|c|c|c|c|c|c|c|c|}
\hline \multirow{2}{*}{ 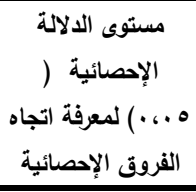 } & \multicolumn{2}{|c|}{ القيمة الفائية (F) } & \multirow[b]{2}{*}{$\overline{7}$} & \multirow[b]{2}{*}{ متوسط المربعات } & \multirow[b]{2}{*}{ المربعات } & \multirow[b]{2}{*}{ التباين } & \multirow[b]{2}{*}{ أسلوب التعلم } & \multirow[b]{2}{*}{ :] } \\
\hline & الجدولية & المحسوية & & & & & & \\
\hline \multirow{3}{*}{ غير دالة إحصائيًا لا } & \multirow{3}{*}{$r, q 9 \leq V$} & \multirow{3}{*}{$1, r \wedge$} & r & $11, .0 r$ & IrY, I $\leq 4$ & المجموعات & \multirow{3}{*}{ الحسي } & \multirow{3}{*}{1} \\
\hline & & & $\wedge \vee \wedge$ & $\varepsilon \wedge, \vee \wedge ५$ & $r r \wedge \cdot, \cdot v r$ & المجموعات & & \\
\hline & & & $\wedge \wedge$. & ه৭,人ז & ro.r, r Iq & المجموع & & \\
\hline \multirow{3}{*}{ غير دالة إحصائيًا لا } & \multirow{3}{*}{$r, q 90 V$} & \multirow{3}{*}{ 1,Arr } & r & $11, . \leq 4$ & $|r|, q \leq V$ & المجموعات & \multirow{3}{*}{ التجريدي } & \multirow{3}{*}{ r } \\
\hline & & & $\wedge \vee \wedge$ & $\varepsilon V, \wedge r V$ & 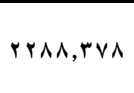 & المجموعات & & \\
\hline & & & $\wedge \wedge$ & $\diamond \wedge, \wedge \wedge$. & r $r 1 \cdot, r r_{0}$ & المجموع & & \\
\hline \multirow{3}{*}{ غير دالة إحصائيًا لا } & \multirow{3}{*}{ Y, १९०V } & \multirow{3}{*}{$1, \varepsilon \ldots$} & r & $11,0 \leq \varepsilon$ & IrY,ADo & المجموعات & \multirow{3}{*}{ التاملي } & \multirow{3}{*}{$r$} \\
\hline & & & $\wedge \vee \wedge$ & $\leq \wedge, \neg, 1$ & rryt,.OV & المجموعات & & \\
\hline & & & $\wedge \wedge$ & $\bullet ৭, \curlyvee \wedge 0$ & $r \leqslant \Lambda \leqslant, q 1 Y$ & المجموع & & \\
\hline \multirow{3}{*}{ غير دالة إحصائيًا لا } & \multirow{3}{*}{ Y, q৭०V } & \multirow{3}{*}{1,111} & r & $11, .97$ & |rr,|r| & المجموعات & \multirow{3}{*}{ التجريبي } & \multirow{3}{*}{$\varepsilon$} \\
\hline & & & $\wedge \vee \wedge$ & $\leq V, Y \leq Y$ & YYTY,IAE & المجموعات & & \\
\hline & & & $\wedge \wedge$ & $\Delta \wedge, r \leqslant r$ & rros,r.o & المجموع & & \\
\hline
\end{tabular}

ويتضح من هذا الجدول عدم وجود فروق ذوات دلالة إحصائية بين طالبات مرحلة الدراسة الإعدادية في

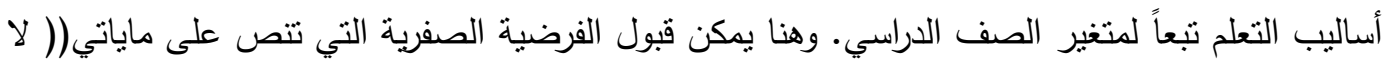
توجد فروق ذوات دلالة إحصائية عند مستوى دلالة (0.. •) بين طالبات مرحلة الدراسة الإعدادية (عيّنة البحث) في أساليب التعلم في ضوء نظرية روميرو و تنبير تبعاً لمتغير الصف الدراسي (الصف الرابع ، الصف الخامس ، الصف الساد) الاعدادي)) وترفض النظرية البديلة التي تتص على مايأتي((توجد 
فروق ذو دلالة إحصائية عند مستوى دلالة (0., ·) بين طالبات مرحلة الدراسة الإعدادية (عيّنة البحث)

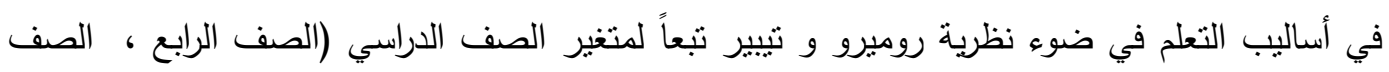
الخامس ، الصف السادس) الاعدادي) إذ يرى (Sims and Sims)(2005) أنّ أساليب التعلم لا تتاثر

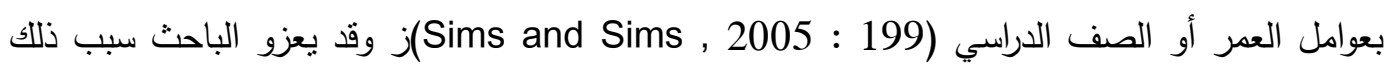
إلى طبيعة عيّنة البحث ووجود ثقارب كبير في المستوى الثقافي و الاجتماعي و الاقتصادي لأفراد هذه

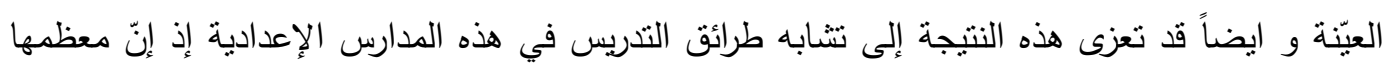

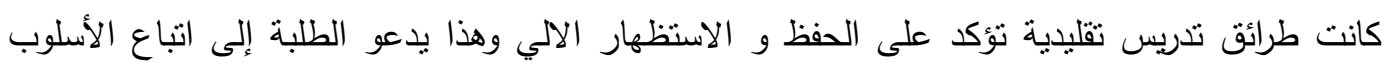

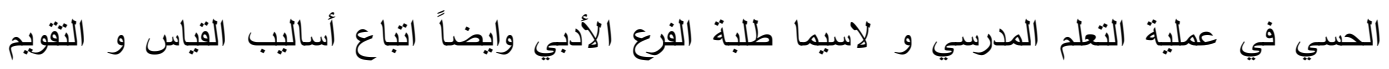

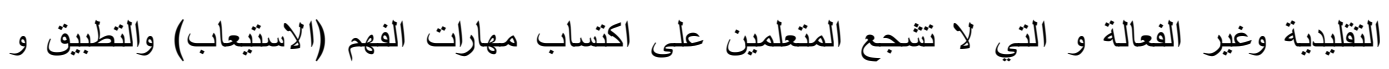

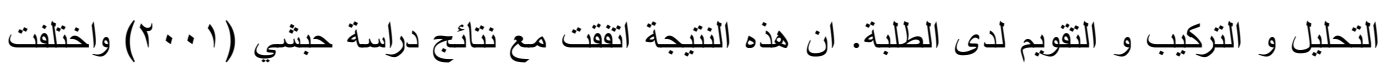

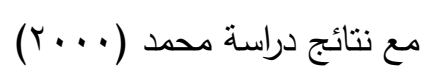

ثاتياً:- الاستثتاجات: في ضوء نتائج هذا البحث نوصل الباحث إلى الاستنتاجات الآتية:-

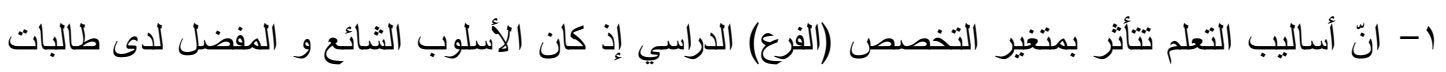

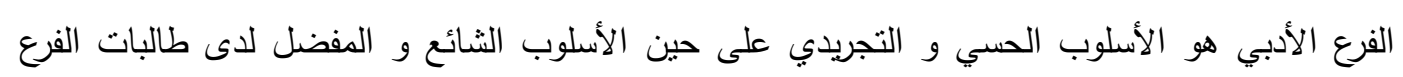

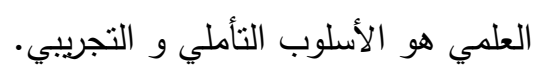

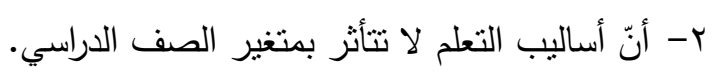

ثالثاً: - التوصيات : - قي ضوء نتائج هذا البحث و استتاجاته تقدم الباحث بالتوصيات الآتية:-

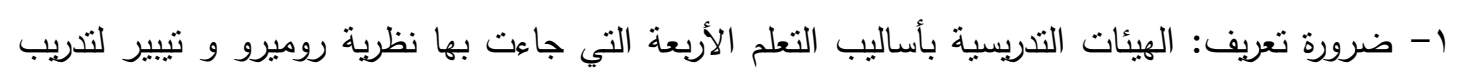

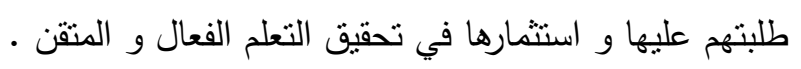

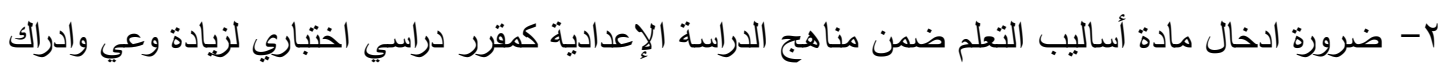

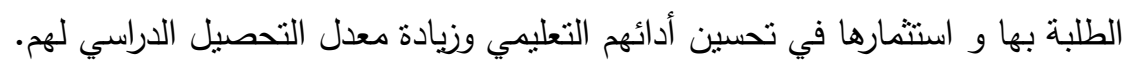


رابعاً:- المقترحات: استكمال لنتائج هذا البحث وتطويراً له يقترح الباحث اجراء الدراسات اللاحقة

الآتية:

1- إجراء دراسة ممانلة على عيّنة من طلبة الدراسة المتوسطة وبمتغيرات أخرى كموقع المدرسة (ريف / مدينة)

$$
\text { ونوع ارتباط المدرسة (حكومي / أهلي ). }
$$

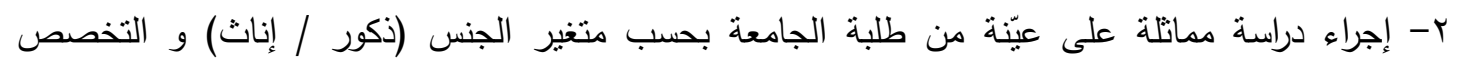
الاراسي (تخصصات علمية و تخصصات إنسانية).

r- علاقة أساليب التعلم بالمتغير الآتية (موقع الضبط / التوجهات الدافعية للإنجاز / التحصيل الدراسي ) الإني (الاكاديمي). 


\section{المصادر}

\section{مجلــــة كليــــة التربيـــة}

العربية

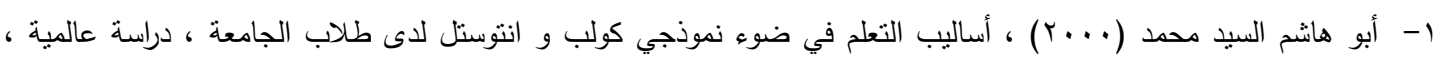

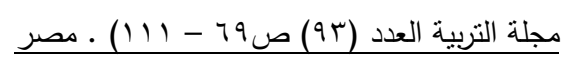

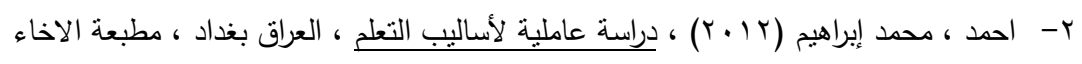

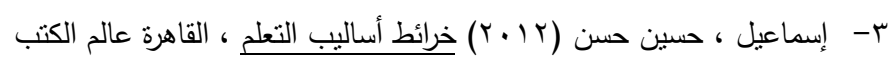

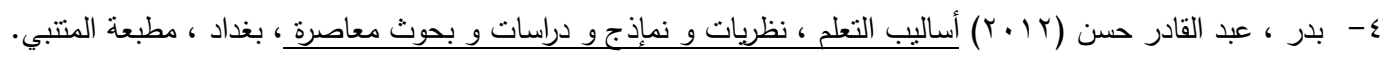

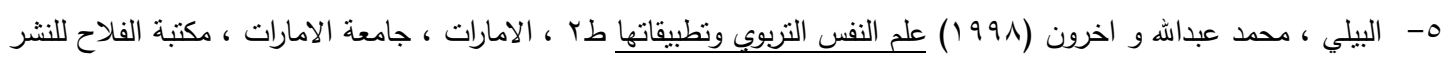
والتوزيع.

צ- جابر ، حسين جبار (10 • ب) أساليب التعلم و التعليم ، العراق بغداد ، مطبعة الخيرات.

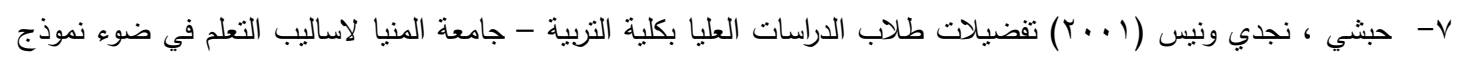

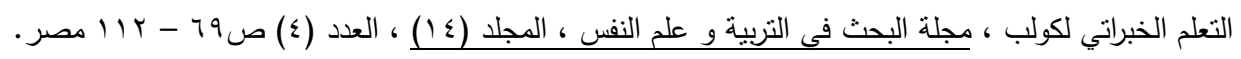

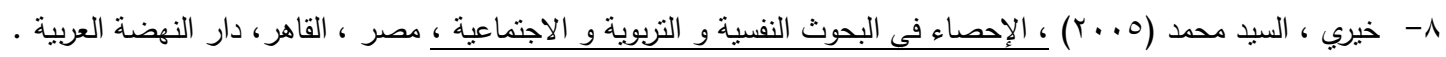

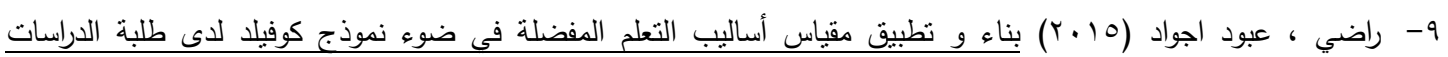
الإعدادية ، العراق ، بغداد ، مطبعة الأمين.

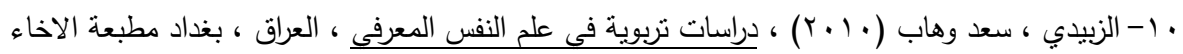

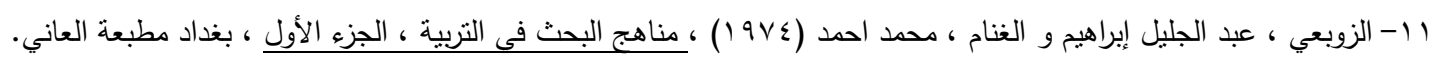

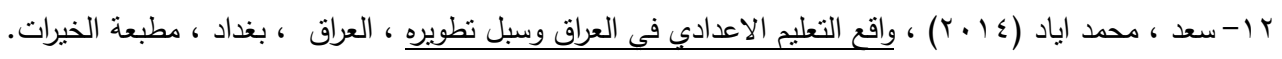

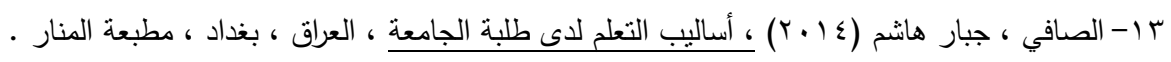

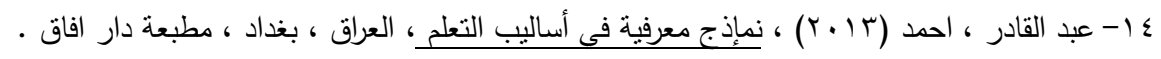

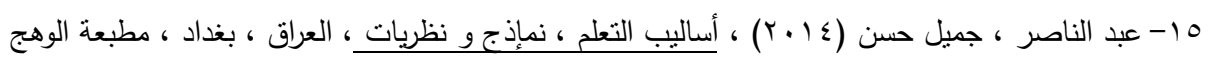

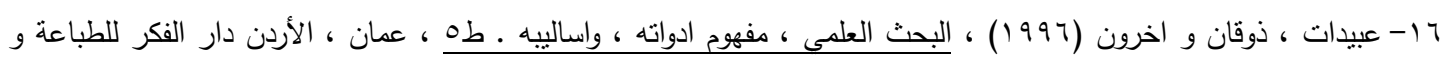
النشر و التوزيع.

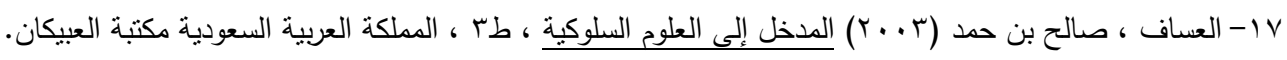

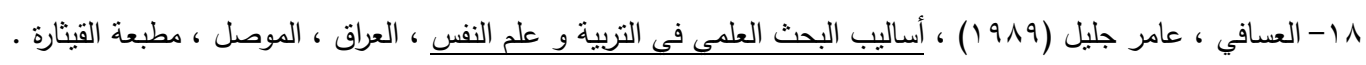

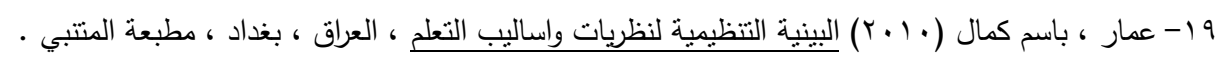

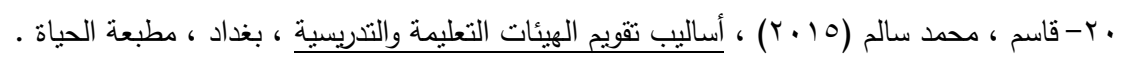

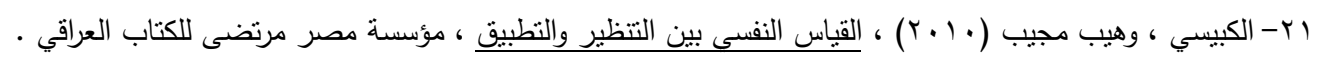

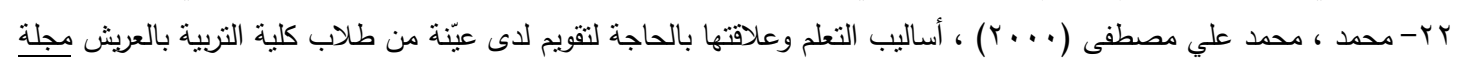

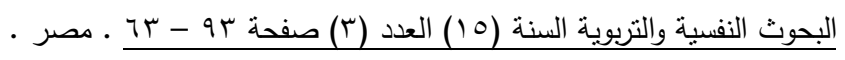




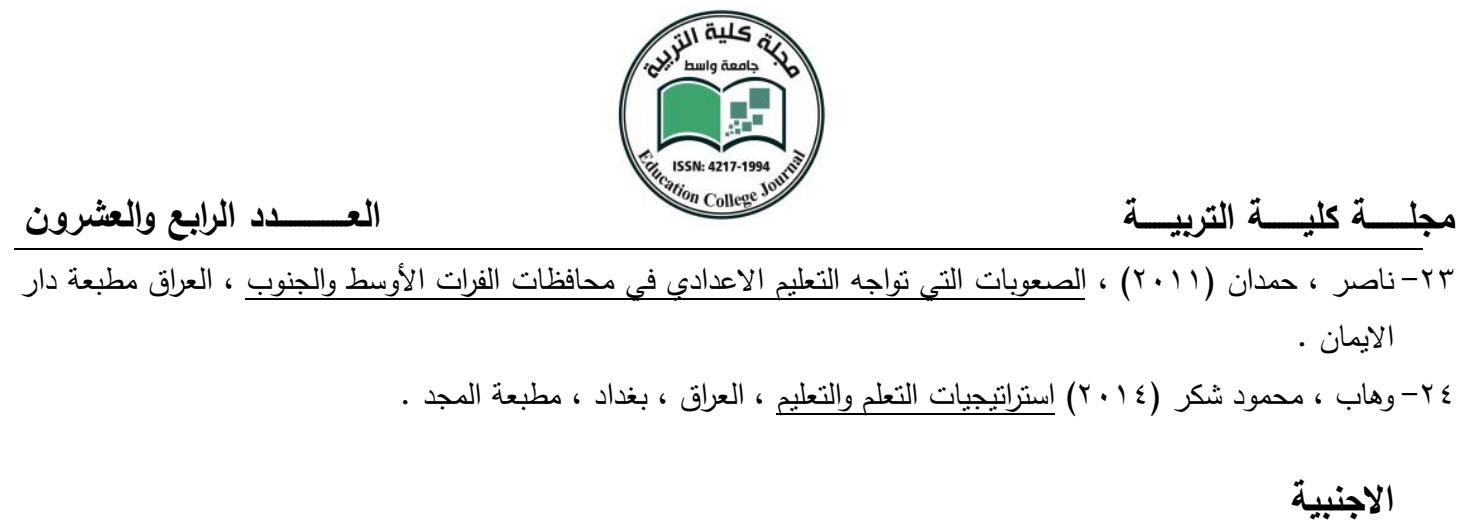

25- Berk . L . (2011) in school Evaluation. London . K.d

26- Chisetal . E.E etal .(1981): Measurement theory $2^{\text {nd }}$ for the Behavioral sciences . freeman.

27- Johassen . D and Grabowaski . B. (2014) Hand . Book of individual Differences Learning and instruction . Lawrence Erlbaum Associales Hills dale. New jersey.

28- Kayes . D. chistopher . (2013)internal validity and reliability of Kolbs Learning style inventory version. U.S.A

29- Nunnly . j (1978) .psychometric theory. $2^{\text {nd }} \cdot$ Ed

30- Romero Jose . E , and Tepper . Bennett. J (1992) learning style Dimensions Educational and psychometric measurement . vol . (52) N (1) pp (171 . 180).

31-Sims .Ronald and Sims serbreniaj (2005) The importance of lrearning styles . understanding the implication for learning course designe and Education.westport green wood press 